\title{
Behaviour of jacked and driven piles in sandy soil
}

\author{
J. YANG*, L. G. THAM*, P. K. K. LEE*, S. T. CHAN† and F. YU*
}

\begin{abstract}
As an alternative to conventional dynamic pile installation methods, pile jacking is an environmentally friendly technique that could become more widely accepted. Great concern has arisen over the performance of jacked piles as compared with that of driven piles. This paper describes a comprehensive field study that was aimed at investigating the differences and similarities between the behaviour of jacked H-piles and that of driven H-piles. The instrumented piles, varying in length from 32 to $55 \mathrm{~m}$ and having a design capacity of up to $3540 \mathrm{kN}$, were installed in residual soils whose properties are close to silty sands. The load test results indicate that the shaft resistance of jacked piles is generally stiffer and stronger than that of driven piles, but the base resistance of jacked piles is weaker than that of driven piles. At a load level of twice the design capacity, the percentage of pile head load carried by base varies from $2 \%$ to $10 \%$ for jacked piles, with a mean value of $6 \%$; for driven piles the percentage varies from $6 \%$ to $61 \%$ with a mean value of $38 \%$. The back-calculated values of the shaft friction coefficient, $\beta$, were found to be in a range of 0.25-0.6 for both jacked and driven piles. A correlation was also observed between the ultimate shaft friction and the mean standard penetration test $N$ value $(\bar{N})$, which suggests that the shaft friction can be taken as $1.5 \bar{N}$ to $2 \bar{N}$ (kPa) for both jacked and driven H-piles.
\end{abstract}

KEYWORDS: bearing capacity; full-scale tests; piles; residual soils; sands
Alternative aux méthodes d'installation dynamiques des piles, l'installation au vérin est une technique respectueuse de l'environnement qui pourrait devenir plus courante. Des doutes ont été émis à propos de la performance de piles vérinées par rapport à celle de piles enfoncées par battage. Cet exposé décrit une étude sur le terrain très complète qui avait pour but d'enquêter sur les différences et les similitudes entre le comportement de piles $H$ vérinées et celui de piles $H$ battues. Des piles instrumentées, variant en longueur de 32 à $55 \mathrm{~mm}$ et ayant des capacités nominales allant jusqu'à $340 \mathrm{kN}$, ont été installées dans des sols résiduels dont les propriétés sont proches de celles de sables limoneux. Les résultas des essais de charge indiquent que la résistance d'arbre des piles vérinées est généralement plus rigide et plus solide que celle des piles battues mais que la résistance de base des piles vérinées est inférieure à celle des piles battues. Avec une charge égale à deux fois capacité nominale, le pourcentage de charge en tête de pile portée par la base varie de $2 \%$ à $10 \%$ pour les piles vérinées, avec une valeur moyenne de $6 \%$; pour les piles battues, le pourcentage varie de $6 \%$ à $61 \%$, avec une valeur moyenne de $38 \%$. Les valeurs rétro-calculées du coefficient de friction de l'arbre, $\beta$, se sont révélées être dans la gamme de 0,25-0,6 à la fois pour les piles vérinées et les piles battues. Une corrélation a également été observée entre la friction d'arbre ultime et la valeur SPTN $(\bar{N})$, ce qui suggère que la friction d'arbre peut être prise comme $1: 5 \bar{N}$ à $2 \bar{N}$ (kPa) tant pour les piles vérinées que pour les piles enfoncées.

\section{INTRODUCTION}

Pile driving involves the use of hammers to provide impacts that are necessary to push a pile into the ground. The noise and ground vibration created by percussion piling are always a nuisance to residents in the vicinity of a foundation construction site, and may lead to damage to nearby structures and facilities. As an alternative to this environmentally unfriendly technique, a method for pile installation that involves the use of hydraulic jacks to press the piles into the ground has received increasing attention. This new technique is essentially free from noise and vibration, and is particularly suitable for installing piles in urban areas.

The capacity of driven piles has been studied extensively in past decades. In particular, there has been a long-standing interest in piles driven in sand and/or sandy soil (Vesic, 1970; Meyerhof, 1976; Randolph et al., 1994; White \& Lehane, 2004). This is partly because the physical process that is involved in driving piles into sand is extremely complicated, and many issues remain to be solved. Of the many factors in the behaviour of sand, two are particularly significant: the relative density and the stress level (Bolton,

Manuscript received 13 July 2005; revised manuscript accepted 3 February 2006.

Discussion on this paper closes on 1 November 2006, for further details see p. ii.

* Department of Civil Engineering, The University of Hong Kong.

$\dagger$ Housing Department, The Government of the Hong Kong Special Administrative Region.
1986; Yang \& Li, 2004). This state dependence, together with the difficulty of modelling the real pile installation process, highlights the limitations of small-scale model tests in capturing the practical behaviour of piles in sand (Craig \& Sabagh, 1994; Fellenius, 2002; Yang, 2005). While some progress in understanding pile behaviour has been made recently through centrifuge model tests (e.g. Klotz \& Coop, 2001; White \& Lehane, 2004), it is well accepted that carefully designed field experiments with highly instrumented piles play a major role in efforts to validate and improve design methods (Randolph, 2003).

Compared with conventional driven piles, the behaviour of jacked piles in sand and/or sandy soil is poorly understood, mainly because of the lack of field experience and a highquality load test database. In a few field studies on the behaviour of driven piles in sand (Lehane et al., 1993; Chow, 1995), jacking was used instead of dynamic driving to prevent damage to instruments on the piles. Inadvertently, these studies provided useful information on the mechanisms involved with jacked piles. Note that the model piles used in these studies were relatively short, and the jacking force used was low (less than $300 \mathrm{kN}$ ). Many practical applications, however, involve long piles and stiff soils, for which a large jacking force is required.

If the jacking technique is to become more widely accepted, then research that is specifically directed at investigating the practical behaviour of jacked piles and the differences and similarities between jacked piles and conventional driven piles is needed. A comprehensive field study 
was hence carried out against this background. The performance of two fully instrumented H-piles when they were jacked and load-tested in dense sandy soils has been described and discussed in detail by Yang et al. (2006). In this paper, our attention is focused on comparisons of the capacity and deformation characteristics of jacked and driven piles, using test data on 14 instrumented H-piles (five jacked and nine driven piles). These test piles had embedded lengths between 32 and $55 \mathrm{~m}$ and design capacity as high as $3540 \mathrm{kN}$. As the soils involved were very stiff, the maximum jacking force used in the tests was in excess of $7000 \mathrm{kN}$. This study aims to allow a better assessment of the suitability of the new technique for pile installation, and to provide an improved understanding of the effect of the installation method on real pile behaviour.

\section{SUBSURFACE CONDITIONS OF TEST SITES}

The field tests described were conducted at two sites in Hong Kong, representing typical ground conditions in this region. The subsurface is normally characterised by a vertical succession of fill, marine deposit, alluvium and decomposed granite. The water tables at both sites were a few metres below the ground. Sufficient boreholes were sunk to confirm the subsurface conditions, and in situ standard penetration tests (SPT) were conducted. Figs 1 and 2 show the detailed profiles of the soil strata and corresponding SPT $N$ values for both sites. Note that the SPT $N$ values generally increase with depth. This is mainly related to the varying degree of weathering of the parent rock.

The fill layers at both sites consist mainly of loose to medium dense, fine to coarse sand with some gravel or sandy silt. The alluvial soil generally consists of interbedding layers of silty and sandy clay and silty fine to coarse sand, occasionally with some fine to medium gravel. The completely decomposed granite (CDG) is a residual soil formed by weathering of the parent rock. This type of residual soil exists widely in Hong Kong and other areas of the world such as Malaysia, Japan and Brazil. Fig. 3 shows the average fine, average coarse and mean curves for the particle grading of the decomposed granite soil in Hong Kong, which were established by Lumb (1962) using 72 samples. As can be seen, the granite soil is composed mainly of slightly clayey and silty sand, with some fine gravel. Its engineering properties are considered to be close to those of permeable silty sand (Lumb, 1962, 1965).

\section{DETAILS OF TEST PILES}

This paper will focus on five jacked piles and nine driven piles, all of which were standard steel H-sections (either 305 $\times 305 \times 180$ or $305 \times 305 \times 223 \mathrm{~kg} / \mathrm{m})$. Driven steel $\mathrm{H}$-piles are popular for the foundations of buildings in Hong Kong, because they can be handled and extended easily. The nine driven piles varied in length from 32 to $55 \mathrm{~m}$, and the embedded lengths of the five jacked piles were between 36 and $41 \mathrm{~m}$. The details of the test piles, including their sizes, embedded lengths and design capacity, are given in Tables 1 and 2.

All of the piles were fully instrumented with strain gauges along their shafts. Fig. 4 schematically shows the arrangement for strain gauges for the jacked and driven piles. Two types of arrangement were used: type A was adopted for driven piles, whereas type B was used for jacked piles, owing to the restriction of the clamping system of the jacking machine used. There were two jacked piles (numbered PJ8 and PJ9) that were installed by a slightly different jacking machine, whose clamping system allowed the type A arrangement to be used.

The spacing of instruments along the pile shaft was generally between 2 and $4 \mathrm{~m}$ for both jacked and driven piles. At each instrument station two strain gauges were installed on the opposite side of the web. For purposes of protection, cables for the strain gauges were fed into a PVC

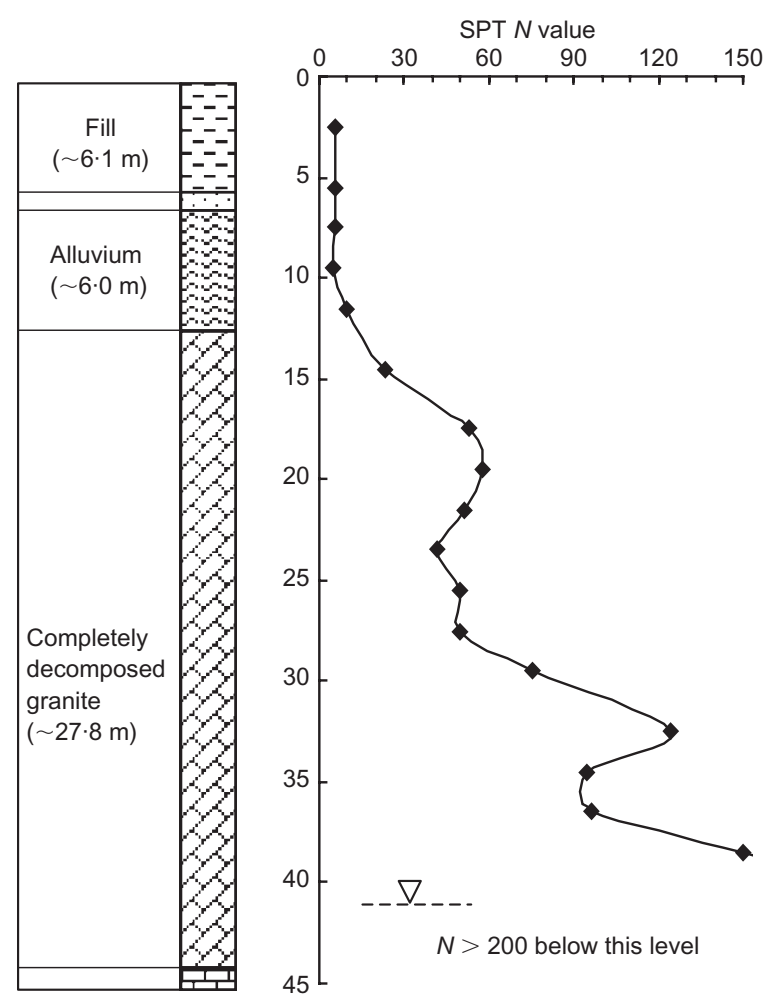

(a)

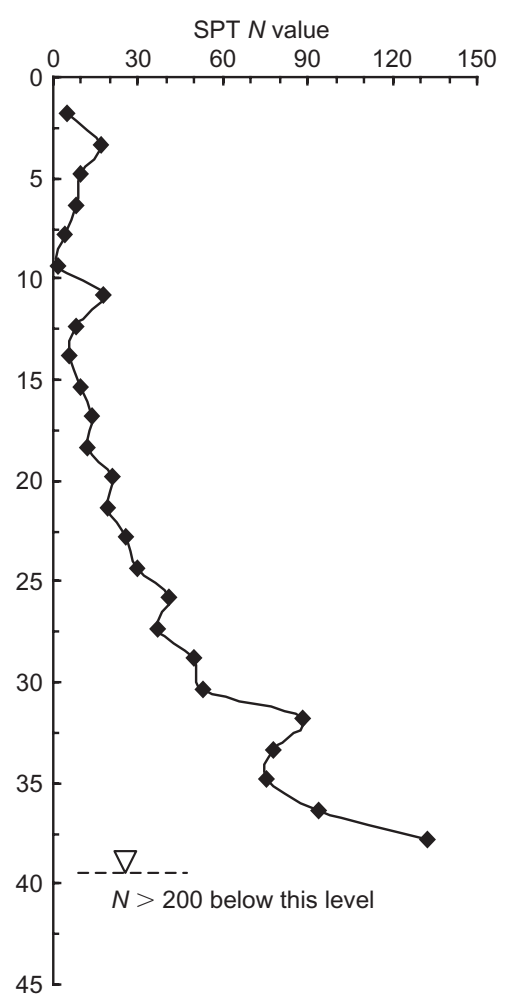

(b)

Fig. 1. Typical soil profiles and SPT $N$ variations at Site A: (a) borehole near PJ1; (b) borehole near PD2 


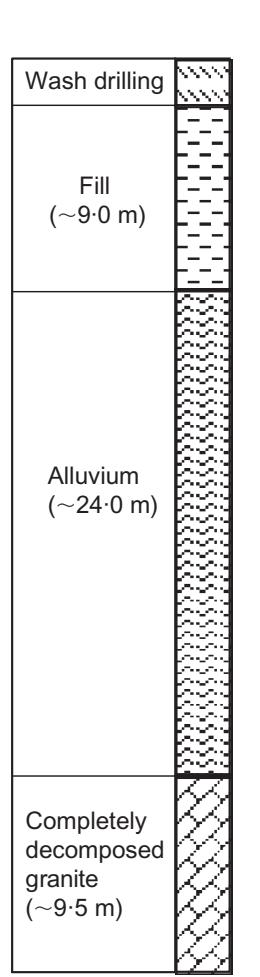

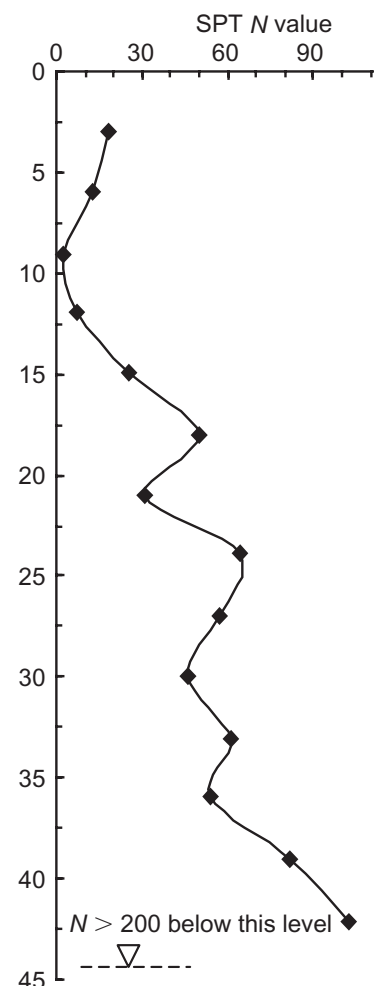

(a)
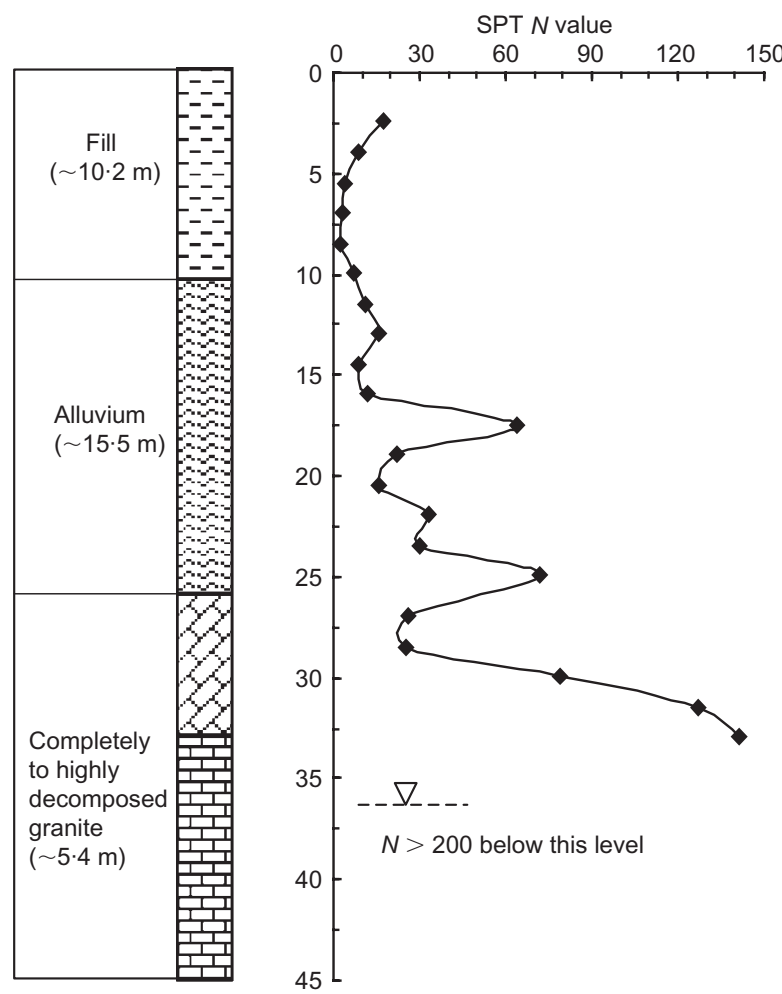

(b)

Fig. 2. Typical soil profiles and SPT $N$ variations at Site B: (a) borehole near PJ8; (b) borehole near PD8

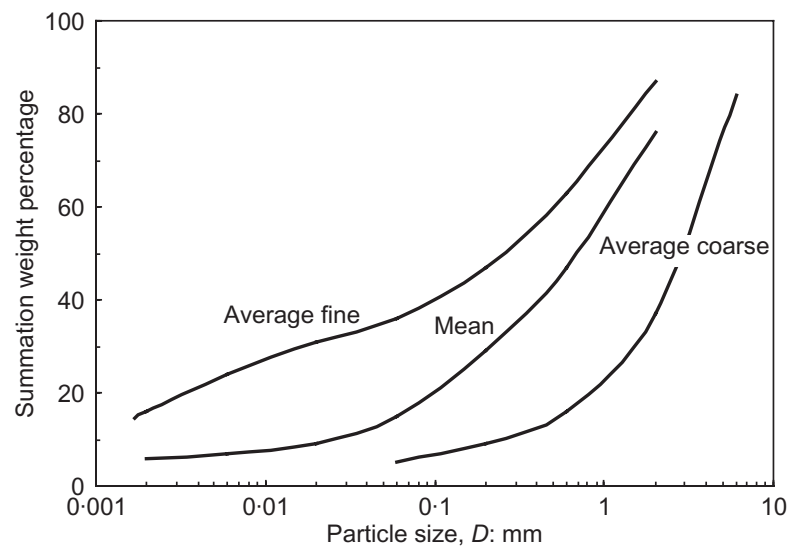

Fig. 3. Grading curves of decomposed granite soil (after Lumb, 1962)

duct on each side; all of the strain gauges and the PVC duct were then covered by a steel angle or U-channel that was welded onto the pile and, further, a solid steel shoe was welded onto the bottom of the steel angle/channel (Figs 4 and 5). These measures have proved to be effective in preventing damage to the instruments during pile installa- tion. Photographs of several instrumented piles are given in Fig. 6.

\section{TERMINATION CRITERIA FOR PILE INSTALLATION}

The jacking machine used to install piles PJ1, PJ6 and PJ7 has a capacity of up to $9000 \mathrm{kN}$, which is supplied by six hydraulic jacks. The maximum jack stroke penetration of the machine is $1.8 \mathrm{~m}$. The jacking machine used to install piles PJ8 and PJ9 is essentially similar, except that it has a lower capacity of $8000 \mathrm{kN}$, supplied by four jacks, and a maximum jack stroke length of $1.6 \mathrm{~m}$. Depending on soil conditions, the penetration rate for all of the five jacked piles was in the range $1-1.8 \mathrm{~m} / \mathrm{min}$; this rate was adjusted to lower values for the last $1-2 \mathrm{~m}$ of penetration.

Unlike dynamically driven piles, for which the final set is commonly used to end the pile driving, there are no wellaccepted termination criteria for pile jacking. Somewhat different termination criteria were therefore used for the five piles in order to examine their effects on pile behaviour. A so-called precreeping procedure (Li et al., 2003), which is conceptually similar to the well-known preloading or surcharging effect in reducing the creep settlement of clay (e.g. Mesri et al., 2001), was adopted. In line with this concept, if a pile is subjected to a jacking load sufficiently larger than its design capacity for a sufficiently long period of

Table 1. Details of jacked piles

\begin{tabular}{|c|c|c|c|c|c|}
\hline Pile no. & PJ1 & PJ6 & PJ7 & PJ8 & PJ9 \\
\hline $\begin{array}{l}\text { Pile size } \\
\text { Design capacity, } P: \mathrm{kN} \\
\text { Embedded length: } \mathrm{m} \\
\text { SPT } N \text { values at pile tip } \\
\text { Location }\end{array}$ & $\begin{array}{c}305 \times 305 \times 223 \\
3540 \\
40 \cdot 9 \\
200 \\
\text { Site } 1\end{array}$ & $\begin{array}{c}305 \times 305 \times 180 \\
2950 \\
39 \cdot 0 \\
154 \\
\text { Site } 3\end{array}$ & $\begin{array}{c}305 \times 305 \times 180 \\
2950 \\
40 \cdot 5 \\
86 \\
\text { Site } 3\end{array}$ & $\begin{array}{c}305 \times 305 \times 180 \\
2950 \\
41 \cdot 5 \\
98 \\
\text { Site } 3\end{array}$ & $\begin{array}{c}305 \times 305 \times 180 \\
2950 \\
35.5 \\
163 \\
\text { Site } 3\end{array}$ \\
\hline
\end{tabular}




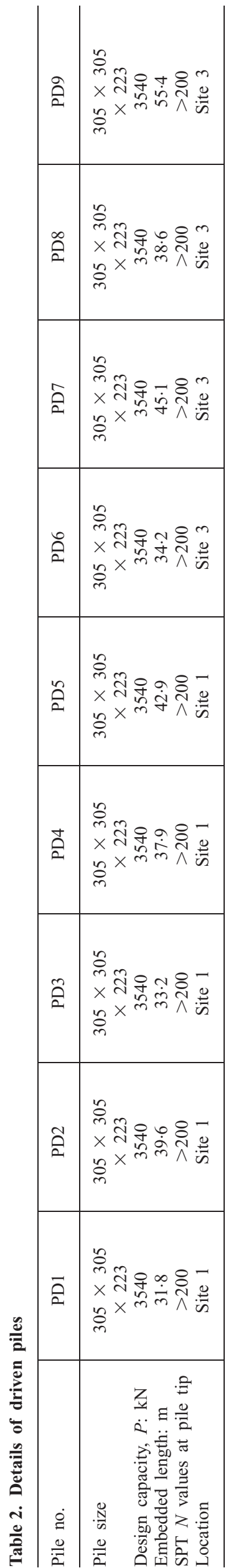

time, then the pile may achieve satisfactory performance when it is re-loaded to its design capacity.

For pile PJ1, precreeping or preloading was carried out at twice the design capacity of the pile in the final stage of jacking. This load level was maintained until the rate of settlement was less than $5 \mathrm{~mm}$ per $15 \mathrm{~min}$. For piles PJ6, PJ8 and PJ9, precreeping was carried out at 2.5 times the design capacity until the target rate of the settlement was achieved, and this preloading cycle was repeated three times. For pile PJ7, five cycles were involved in the termination process, in which the level of jacking load varied from $2 \cdot 2$ to 2.5 times the design capacity. As will be discussed later, the termination criteria used in ending pile installation can have a marked impact on the behaviour of the jacked piles.

For driven piles, the final set for the termination of pile driving is normally evaluated using pile-driving formulae. In Hong Kong, the Hiley formula (GEO, 1996) is widely used. This relates the resistance of the pile $R$ to the final set $s$ as

$$
R=\frac{\eta W H}{s+c / 2}
$$

where $W$ is the weight of the hammer, $H$ is the height of fall of the hammer, $\eta$ is the efficiency of the hammer, and $c$ is the elastic or recoverable compression of the pile and the cushioning assembly at the pile head.

Given a specified pile-driving machine and site condition, the final set can be readily estimated from equation (1). Local experience indicates that driven piles for which driving is terminated by the final-set criterion can usually penetrate into a soil stratum with SPT $N$ values greater than 200 . Note that the piles installed by hydraulic jacking, however, were able to penetrate only into relatively weaker soil strata (see Table 1).

\section{ACCEPTANCE CRITERIA FOR PILE LOAD TESTS}

After installation of all the piles by hydraulic jacking or dynamic driving, static loading tests were carried out using the slow maintained-load (ML) procedure. The procedure that was adopted for all piles except for PJ7 comprised three load cycles. In the first cycle, the pile was loaded in two equal increments to its design capacity and then was unloaded completely. In the second cycle, the test load was reapplied in four equal increments to twice the design capacity and maintained for $72 \mathrm{hr}$ before removal. In the third cycle, the pile was loaded in increments to the allowable maximum load and then released completely. The load at each incremental stage in the tests was held for a period of $10 \mathrm{~min}$ until the rate of head settlement was less than $0.05 \mathrm{~mm}$ in $10 \mathrm{~min}$. The procedure used for testing pile PJ7 was similar but involved a few more cycles of loading.

The acceptance criteria adopted for static loading tests are commonly related to settlement limits (Tomlinson, 1994). There are several sets of acceptance criteria that have been generally accepted, such as the $90 \%$ criterion proposed by Hansen (1970) and the criterion suggested by Davisson (1972). In Hong Kong, the settlement criteria that are adopted by most government authorities for test piles include allowable settlement limits for both the total and residual settlement (GEO, 1996; BD, 2004). In other words, test piles are considered to be satisfactory only if both settlement limits are not exceeded.

The modified Davisson method, specified by local authorities, was used in this study as the acceptance criterion for both the jacked and driven piles. The allowable total settlement (in $\mathrm{mm}$ ) at pile head during a maintained load test to twice the design capacity (in $\mathrm{kN}$ ), $P$, is determined by 

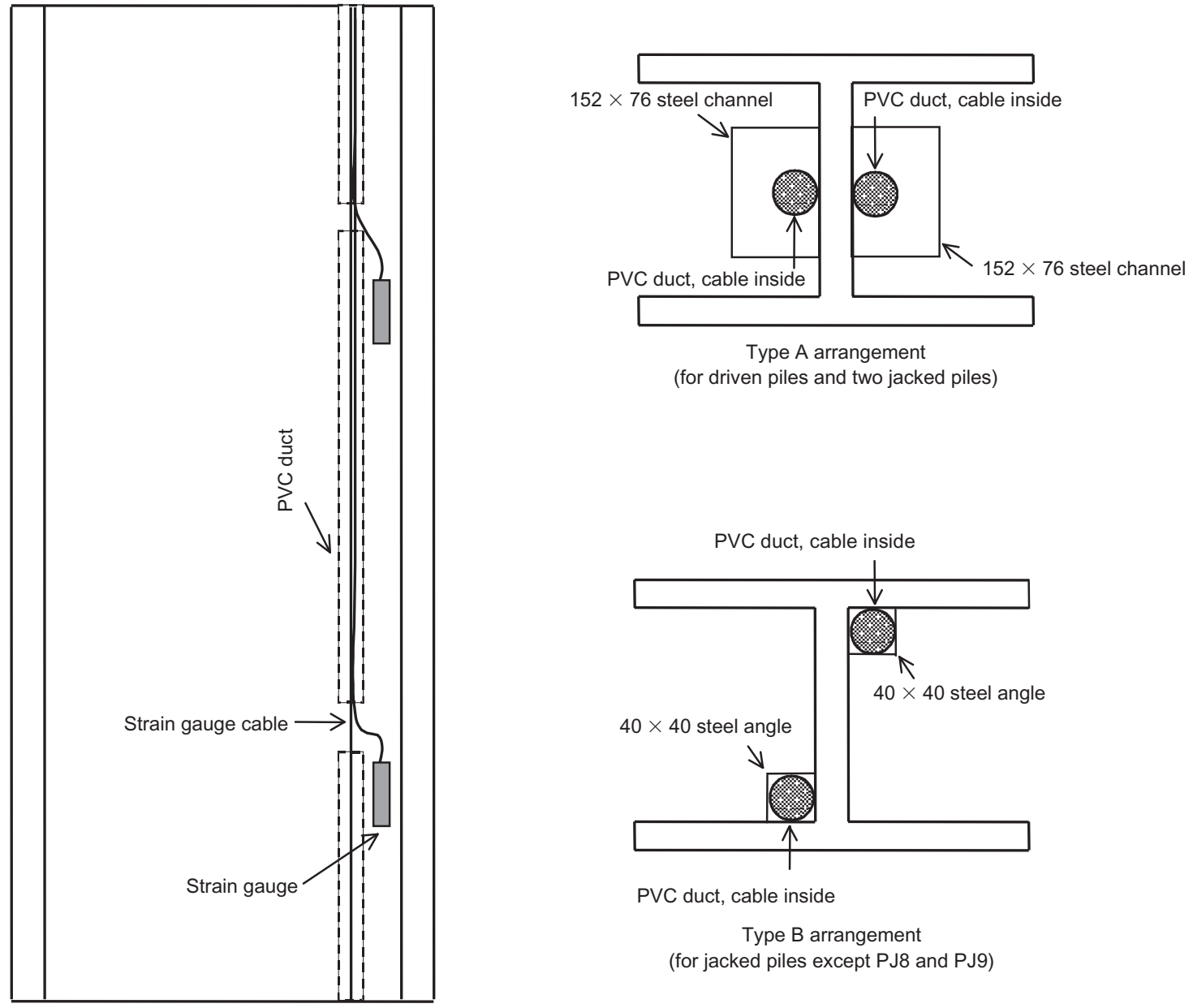

Fig. 4. Schematic illustration of strain gauge arrangement (not to scale)

$$
S_{\text {all-total }}=\frac{2 P L}{E A}+\frac{D}{120}+4
$$

in which $L$ is pile length (in mm), $A$ is the cross-sectional area of the pile (in $\mathrm{mm}^{2}$ ), $E$ is the Young's modulus for the material of the pile (in $\mathrm{kN} / \mathrm{mm}^{2}$ ), and $D$ is the least lateral dimension of the pile (in $\mathrm{mm}$ ). For the $305 \times 305 \times$ $180 \mathrm{~kg} / \mathrm{m}$ and $305 \times 305 \times 223 \mathrm{~kg} / \mathrm{m}$ steel $\mathrm{H}$-sections used in this study, $D$ equals $0.320 \mathrm{~m}$ and $0.325 \mathrm{~m}$ respectively.

It is clear that the allowable total settlement expressed in equation (2) has two components: the elastic shortening of the pile shaft at twice the design capacity under the assumption that the pile is free standing, and the permanent or residual settlement that is locked in when the applied load is released (Fig. 7). The allowable residual settlement (in $\mathrm{mm}$ ) at a head load of zero is given as

$$
S_{\text {all-res }}=\frac{D}{120}+4
$$

For clarity, it should be mentioned that the maximum load determined for a pile in the final loading stage of the test, $Q_{\max }$ (see Tables 3 and 4), was taken to be the smaller one between the capacity of the loading system and the load determined using the total allowable settlement criterion: that is, the head settlement corresponding to the maximum applied load $\mathrm{S}_{\max }$ (in $\mathrm{mm}$ ) should not exceed the allowable one. The key values of various settlements that were recorded during the tests are given in Tables 3 and 4 for all test piles. Note that if the residual settlement of a pile was recorded to be negative, it was assigned a zero in the tables.

\section{OBSERVED LOAD TRANSFER MECHANISMS}

Static load tests on instrumented piles allow a separation of the applied load at the pile head into shaft and base resistance. Fig. 8 shows the axial stress distribution at various load levels for two selected jacked piles, PJ1 and PJ8, and Fig. 9 presents the axial stress distribution for two driven piles, PD2 and PD8. Note that all the results were derived from the readings of strain gauges that were taken during the final loading cycle when piles were loaded to their maximum loads. It should also be mentioned that the residual stresses locked in the piles after installation were ignored in the data interpretation in this paper. In other words, a common practice of zeroing the instruments before the load tests was followed.

Comparison of Figs 8 and 9 suggests that the load transfer mechanism of jacked piles differs from that of driven piles. The change of the axial loads along the shaft of driven piles was slight, implying that small shaft resistance was mobilised. The axial loads in the jacked piles, however, appeared to reduce with depth more significantly, implying that larger shaft resistance was mobilised.

The shaft friction profiles deduced from the axial load distribution are shown in Figs 10 and 11 for the jacked and driven piles respectively. Compared with the jacked piles, the shaft friction profiles of the two driven piles exhibit different features. Generally, the driven piles show weaker shaft resistance than the jacked piles. For the jacked piles, very large shaft resistance was measured along the lower parts that were embedded in the decomposed granite strata. For example, under the maximum load (2.2 times the pile design capacity), a shaft friction of up to $150 \mathrm{kPa}$ was recorded on PJ1 between depths of $27-31 \mathrm{~m}$ and $35-39 \mathrm{~m}$. 

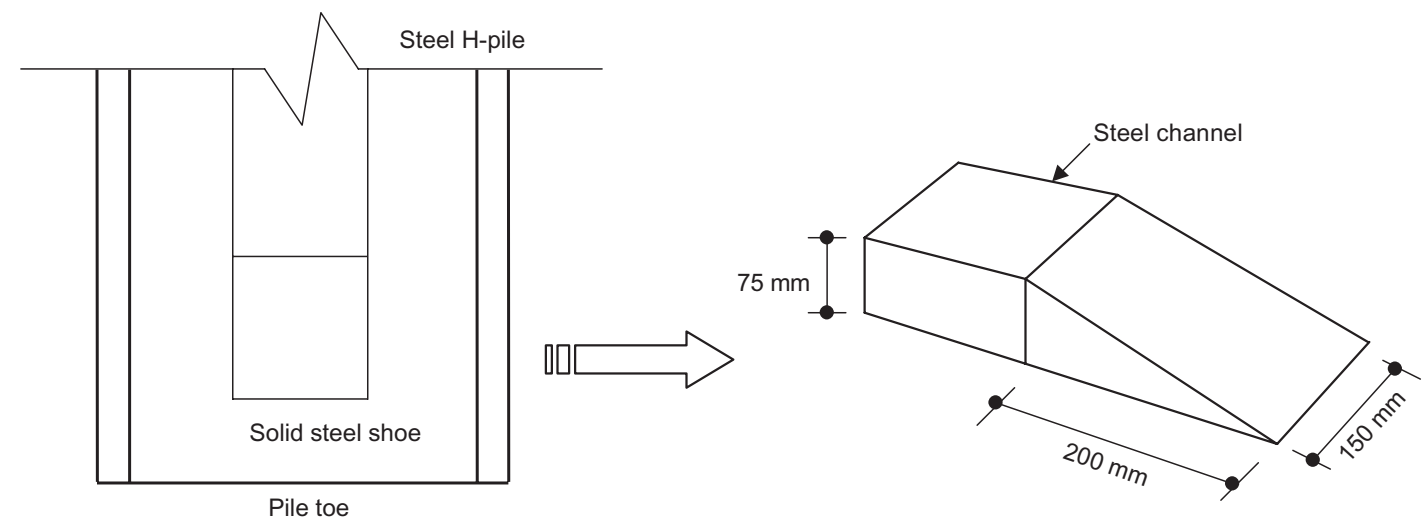

(a)
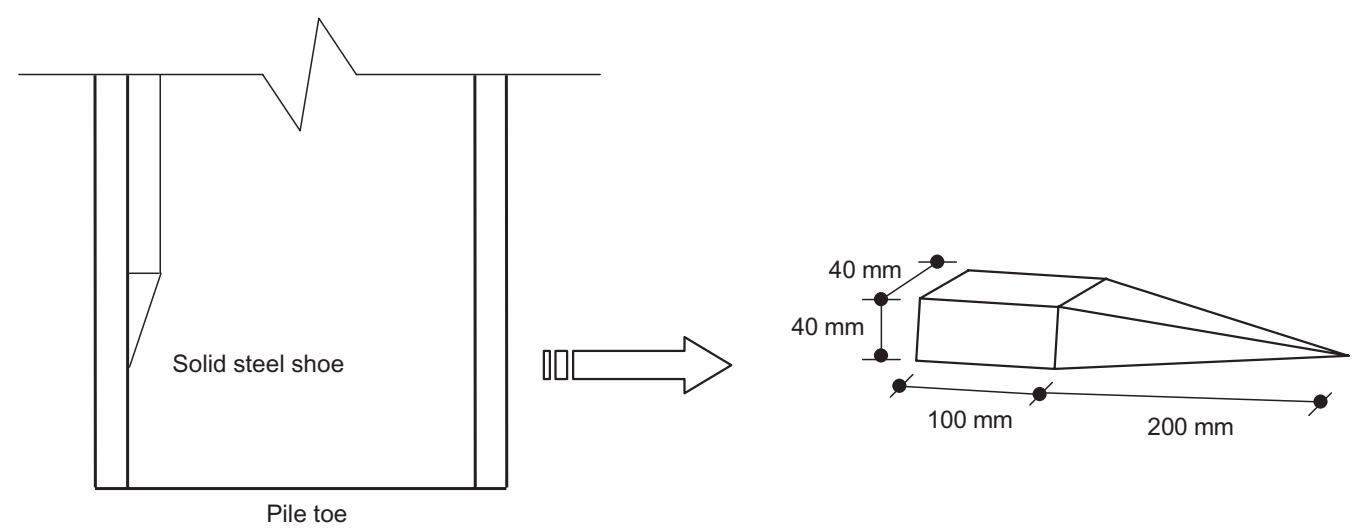

(b)

Fig. 5. Schematic illustration of steel shoes used in tests (not to scale): (a) shoes for type A arrangement; (b) shoes for type $B$ arrangement
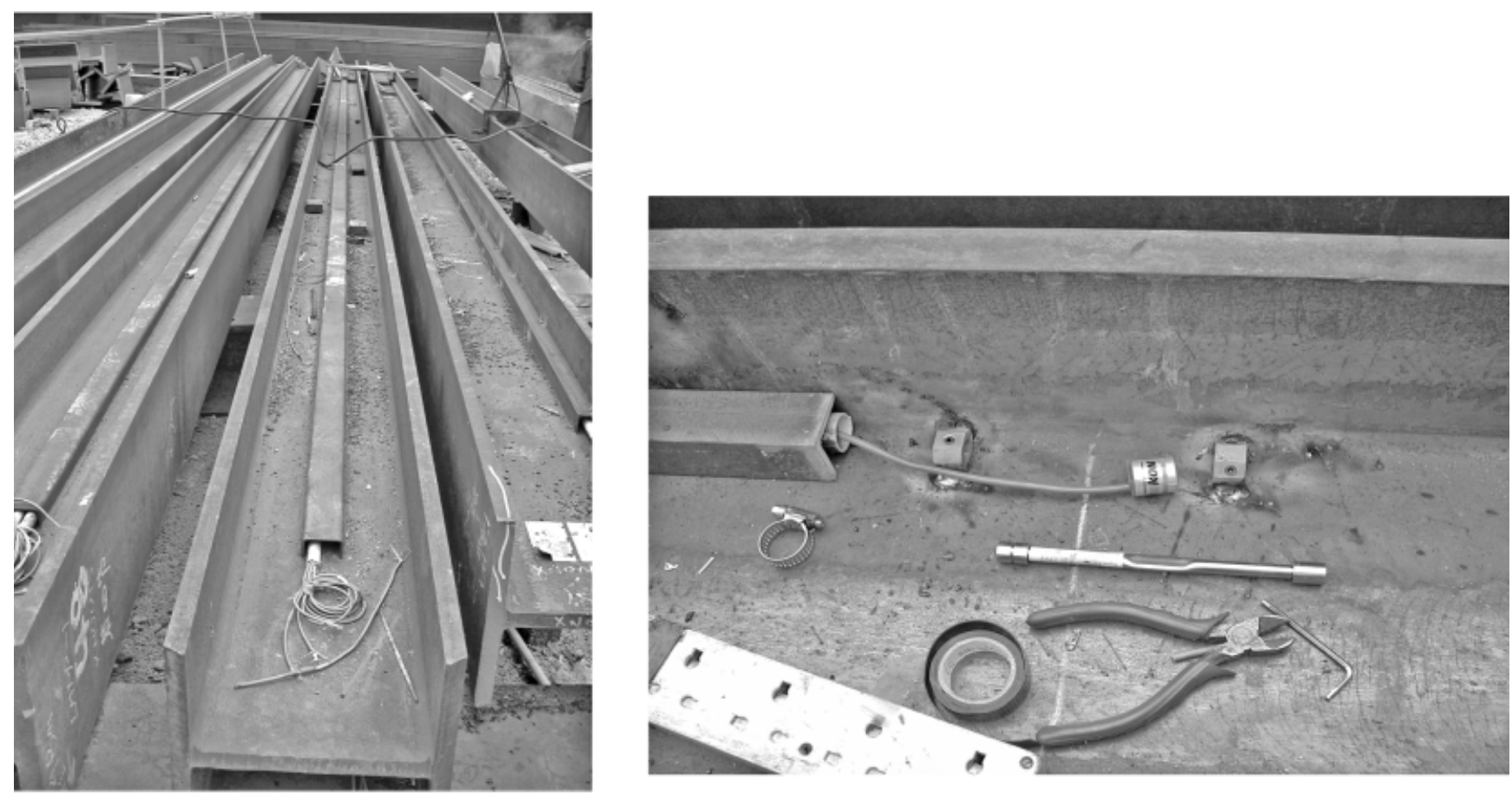

Fig. 6. Instrumented piles

An even greater shaft friction (in excess of $350 \mathrm{kPa}$ ) was recorded on PJ8 at depths of $37-40 \mathrm{~m}$ at a load level of $3 \cdot 3$ times the design capacity.

There is an observation that deserves particular attention:
PJ8 showed a much higher load-carrying capacity than PJ1, although its design capacity was lower than that of PJ1 and its embedded length was close to that of PJ1. This discrepancy is considered attributable to the different termination 


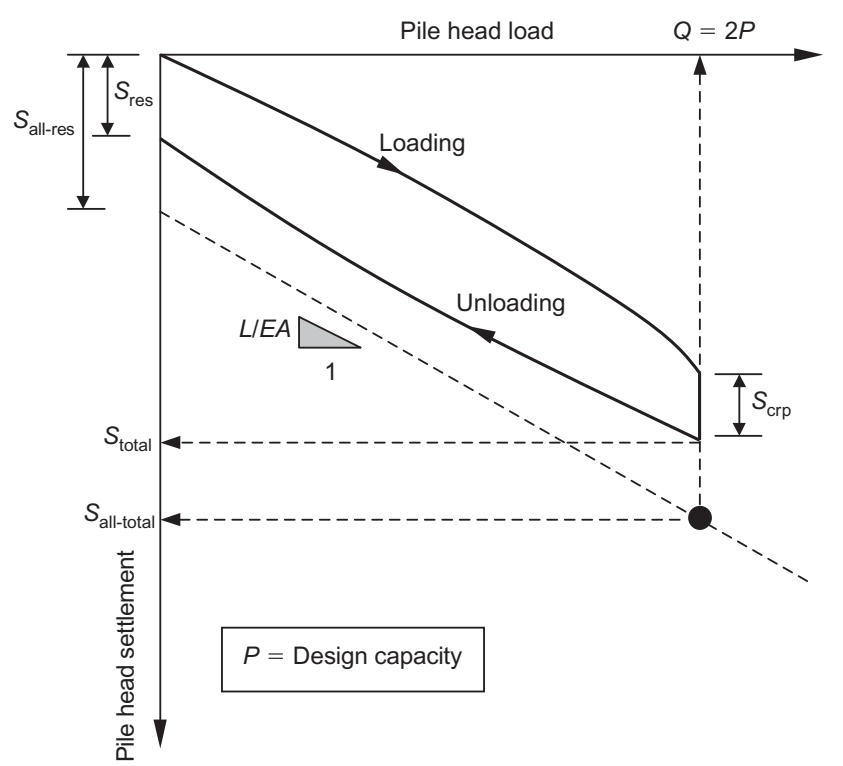

Fig. 7. Schematic diagram of acceptance criteria adopted for static load tests

criteria used for the two piles during the final stages of jacking. Note that the final jacking force that was used in the termination process for PJ8 was 2.5 times its design capacity, as compared with 2.0 times the design capacity for PJ1.

There are a few anomalous values of shaft resistance at several locations for both the jacked and driven piles, such as the negative shaft friction observed on PJ8 at a depth of $10-15 \mathrm{~m}$. While further exploration of the potential reasons (e.g. residual stress effect, influence of soft layer) would be beneficial, these anomalous values are presumably considered to be due to rogue strain gauge measurements.
To have a better view of the load distribution between shaft and base, the percentages of pile head load carried by the base are calculated for all of the test piles, and shown in Fig. 12 as a function of the applied load at pile head. The following major observations can be made by comparing the two figures for the jacked and driven piles.

(a) The base resistance of both the jacked and the driven piles is increasingly mobilised as the pile head loads increase.

(b) At a load level of twice the design capacity, the percentage of head load carried by base varies from $2 \%$ to $10 \%$ for the jacked piles, with a mean value of about $6 \%$.

(c) For driven piles at the same load level, the percentage varies from $6 \%$ to $61 \%$, with a mean value of about $38 \%$.

The values of percentage for PJ1 are smaller than those given in Yang et al. (2006) because of an improved interpretation used herein.

It should be noted that there is a small cluster of driven piles (i.e. PD1, PD5, and PD7) whose mobilised base resistance appears to be significantly lower than that of the majority of the driven piles. This might be linked to a weaker bearing layer existing beneath the pile tip, but there is no clue in the ground conditions or driving records that allows a definite explanation. If the three piles are excluded, the average value of the percentage for driven piles will increase from $38 \%$ to about $50 \%$. This is much greater than the mean value for the jacked piles $(6 \%)$. In this regard, it can be stated that the jacked piles derived their resistance predominantly from shaft friction, whereas the overall loadcarrying capacity of the driven piles was more evenly distributed between shaft and base.

Table 3. Measured shaft and base resistance of jacked piles

\begin{tabular}{l|c|c|c|c|c}
\hline Pile no. & PJ1 & PJ6 & PJ7 & PJ8 & PJ9 \\
\hline Maximum load, $Q_{\max }: \mathrm{kN}$ & 7788 & 8850 & 9735 & 9735 & 8555 \\
Shaft resistance, $Q_{\mathrm{s}}: \mathrm{kN}$ & 6594 & 8208 & 8426 & 9396 & 7608 \\
Base resistance, $Q_{\mathrm{b}}: \mathrm{kN}$ & 1194 & 642 & 1309 & 339 & 947 \\
Ratio $Q_{\mathrm{s}} / Q_{\max }$ & $0 \cdot 847$ & $0 \cdot 927$ & $0 \cdot 866$ & 0.965 & $0 \cdot 889$ \\
Ratio $Q_{\mathrm{b}} / Q_{\max }$ & $0 \cdot 153$ & $0 \cdot 073$ & $0 \cdot 134$ & $0 \cdot 035$ & $0 \cdot 111$ \\
Maximum settlement, $S_{\max }: \mathrm{mm}$ & $87 \cdot 58$ & $94 \cdot 15$ & $70 \cdot 50$ & $69 \cdot 81$ & $74 \cdot 83$ \\
Creep settlement, $S_{\text {crp }}: \operatorname{mm}$ & $11 \cdot 16$ & $0 \cdot 95$ & $0 \cdot 40$ & $1 \cdot 25$ & $1 \cdot 47$ \\
Residual settlement, $S_{\text {res }}: \mathrm{mm}$ & $9 \cdot 76$ & $0 \cdot 04$ & $0 \cdot 25$ & $1 \cdot 61$ & $0 \cdot 87$ \\
\hline
\end{tabular}

Note: $S_{\max }=$ total settlement recorded at maximum load in third load cycle; $S_{\text {crp }}=$ creep settlement recorded during maintaining period in second load cycle; $S_{\text {res }}=$ residual settlement recorded after removal of maintained load.

Table 4. Measured shaft and base resistance of driven piles

\begin{tabular}{l|c|c|c|c|c|c|c|c|c}
\hline Pile no. & PD1 & PD2 & PD3 & PD4 & PD5 & PD6 & PD7 & PD8 & PD9 \\
\hline Maximum load, $Q_{\max }: \mathrm{kN}$ & 11682 & 10266 & 11328 & 11328 & 10974 & 9225 & 10289 & 11708 & 9580 \\
Shaft resistance, $Q_{\mathrm{s}}: \mathrm{kN}$ & 7869 & 4298 & 5129 & 5511 & 9615 & 3448 & 8975 & 4369 & 4211 \\
Base resistance, $Q_{\mathrm{b}}: \mathrm{kN}$ & 3813 & 5968 & 6199 & 5817 & 1359 & 5777 & 1314 & 7339 & 5369 \\
Ratio $Q_{\mathrm{s}} / Q_{\max }$ & $0 \cdot 674$ & $0 \cdot 419$ & $0 \cdot 453$ & $0 \cdot 486$ & $0 \cdot 876$ & $0 \cdot 374$ & $0 \cdot 872$ & $0 \cdot 373$ & $0 \cdot 439$ \\
Ratio $Q_{\mathrm{b}} / Q_{\max }$ & $0 \cdot 326$ & $0 \cdot 581$ & $0 \cdot 547$ & $0 \cdot 514$ & $0 \cdot 124$ & $0 \cdot 626$ & $0 \cdot 128$ & $0 \cdot 627$ & $0 \cdot 561$ \\
Maximum settlement, $S_{\max }: \mathrm{mm}$ & $74 \cdot 48$ & $101 \cdot 45$ & $64 \cdot 49$ & $70 \cdot 91$ & $81 \cdot 74$ & $52 \cdot 01$ & $89 \cdot 60$ & $79 \cdot 31$ & $89 \cdot 75$ \\
Creep settlement, $S_{\text {crp }}: \mathrm{mm}$ & $1 \cdot 42$ & $2 \cdot 27$ & $1 \cdot 06$ & $0 \cdot 74$ & $1 \cdot 44$ & $0 \cdot 92$ & $1 \cdot 20$ & $0 \cdot 70$ & $1 \cdot 82$ \\
Residual settlement, $S_{\text {res }}: \mathrm{mm}$ & 0 & 0 & $2 \cdot 07$ & $0 \cdot 32$ & $1 \cdot 17$ & 0 & 0 & 0 & $3 \cdot 02$ \\
\hline
\end{tabular}

Note: $S_{\max }=$ total settlement recorded at maximum load in third load cycle; $S_{\mathrm{crp}}=$ creep settlement recorded during maintaining period in second load cycle; $S_{\text {res }}=$ residual settlement recorded after removal of maintained load. 


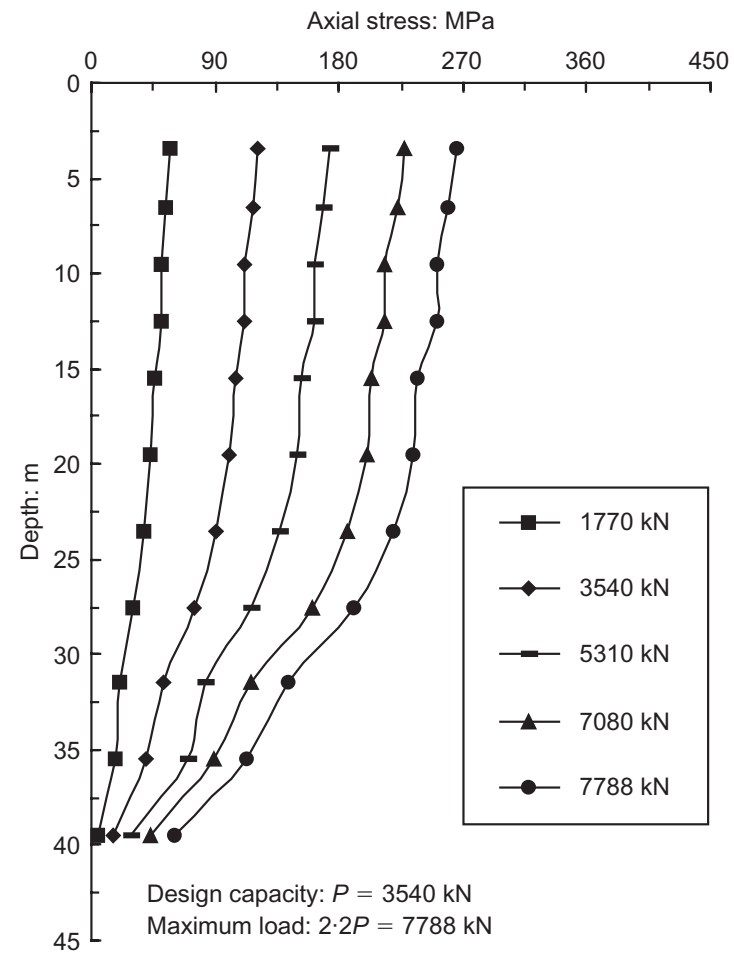

(a)

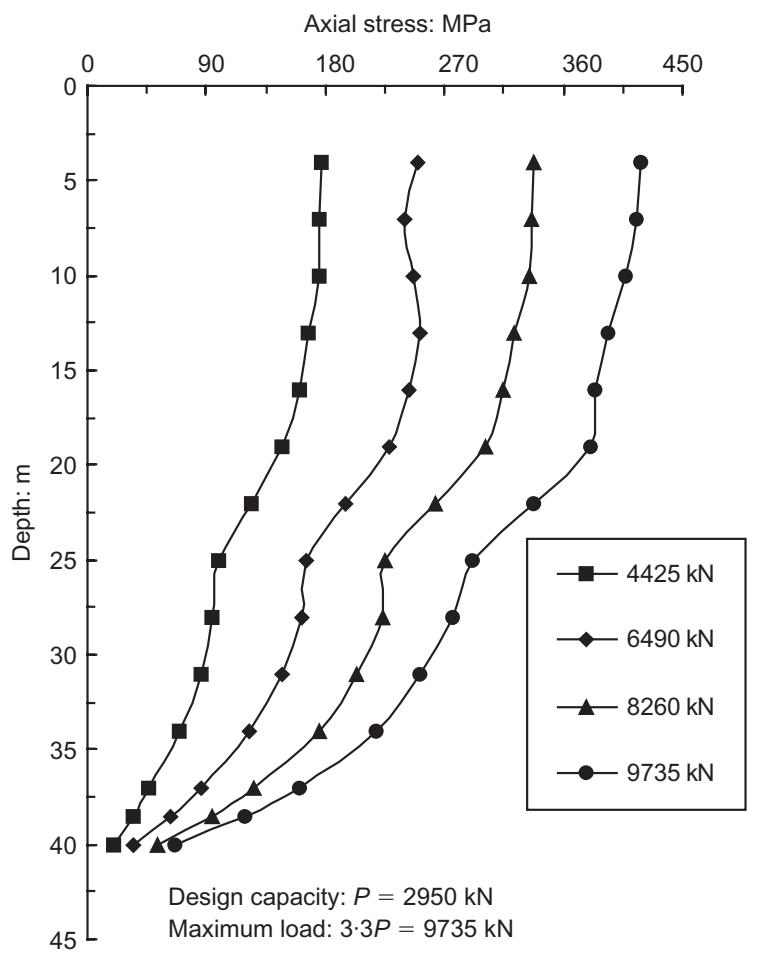

(b)

Fig. 8. Typical axial load distribution for jacked piles: (a) PJ1; (b) PJ8

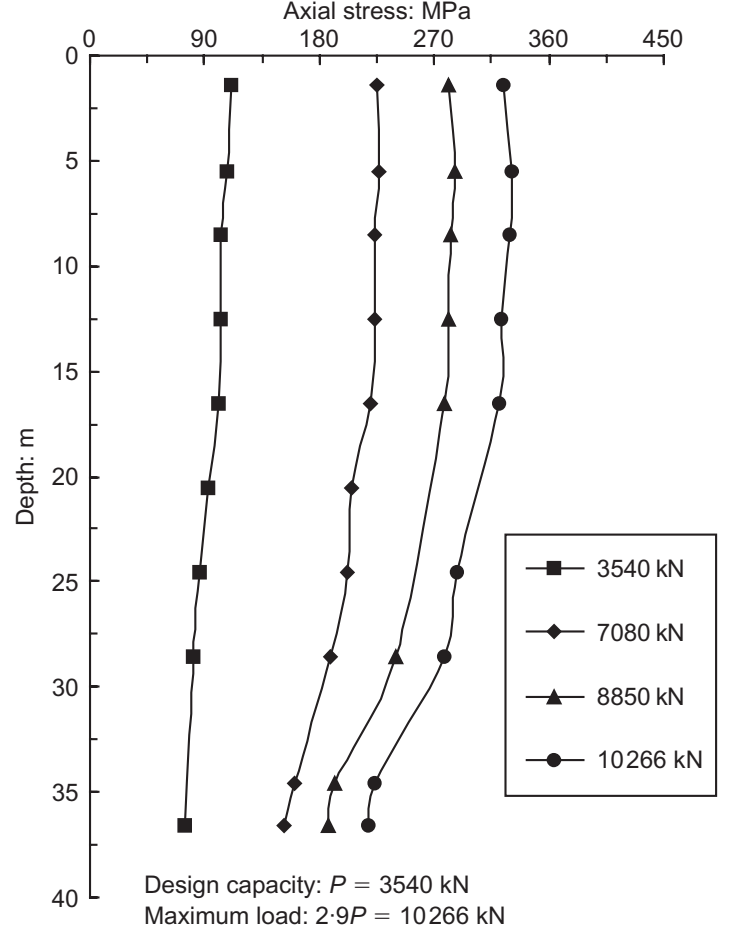

(a)

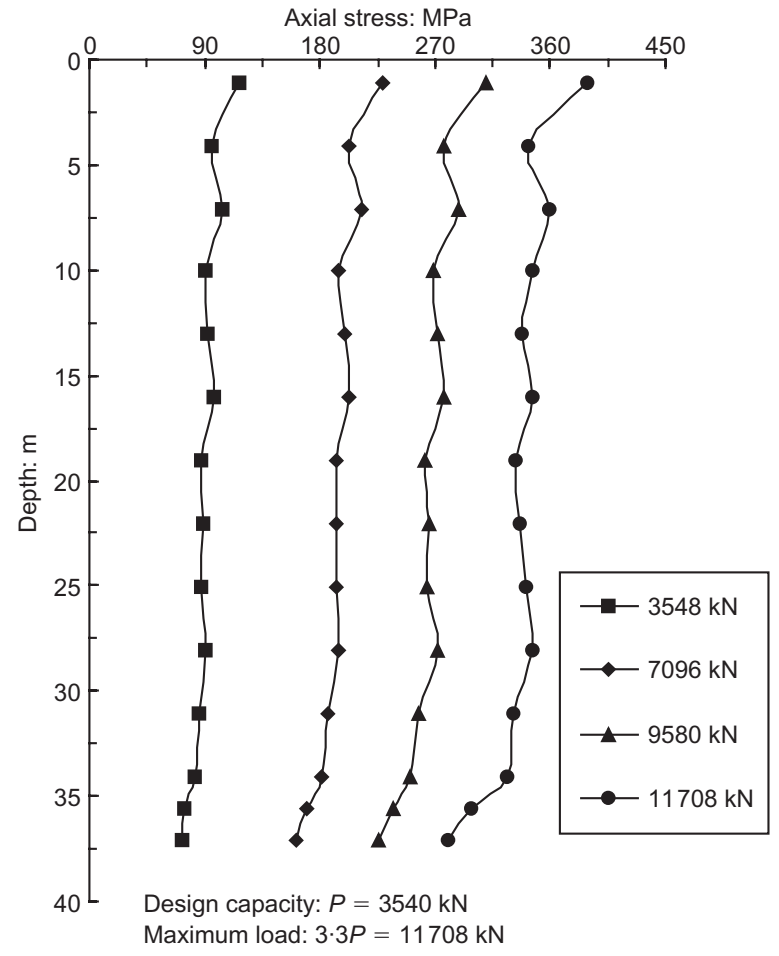

(b)

Fig. 9. Typical axial load distribution for driven piles: (a) PD2; (b) PD8

\section{OBSERVED LOAD-DEFORMATION \\ CHARACTERISTICS}

This section is to further examine and compare the loaddeformation behaviour of jacked and driven piles. Shown in Fig. 13 is the measured relationship between pile head load and cumulative head settlement for two jacked piles, PJ1 and PJ8, and Fig. 14 presents the load-settlement curves for two driven piles, PD2 and PD8.

Comparison of the two diagrams in Fig. 13 suggests that pile PJ1 was loaded to plunging failure but pile PJ8 showed no sign of failure, even under a load level of $3 \cdot 3$ times its design capacity. Under a load of twice the design capacity 


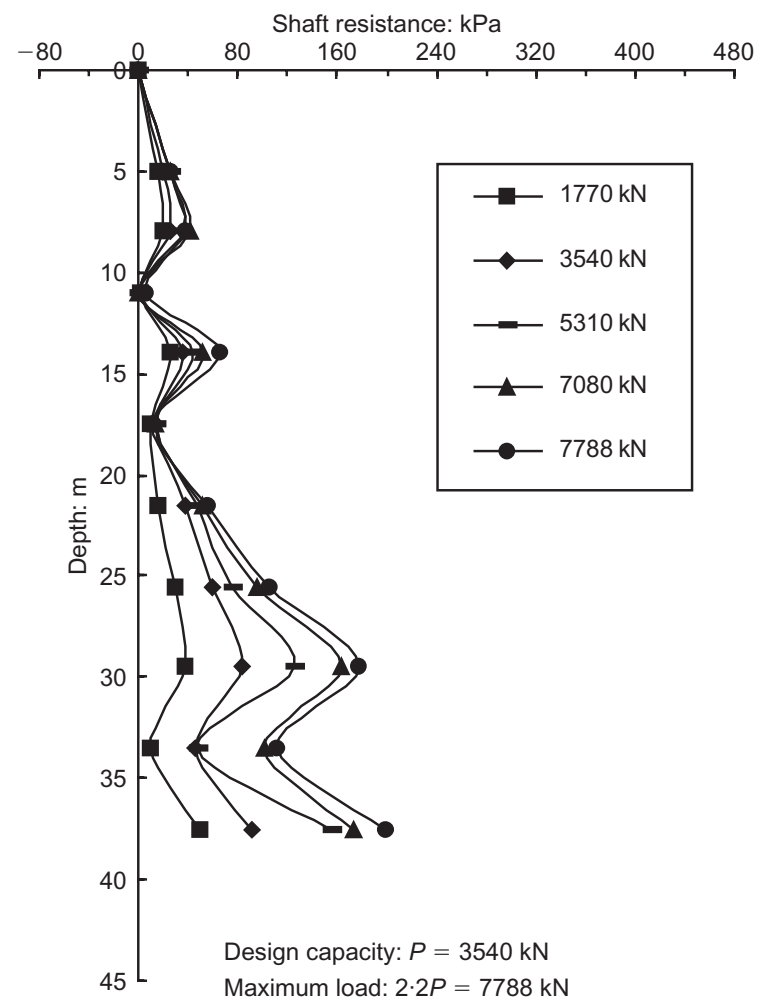

(a)

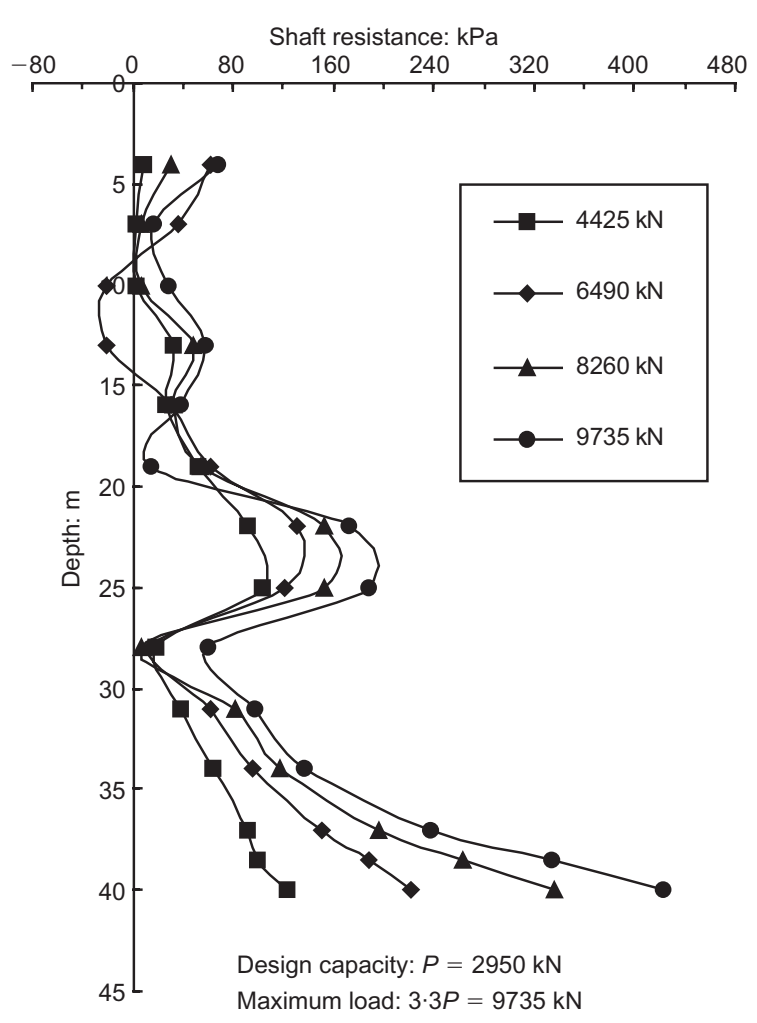

(b)

Fig. 10. Shaft resistance distribution for jacked piles: (a) PJ1; (b) PJ8

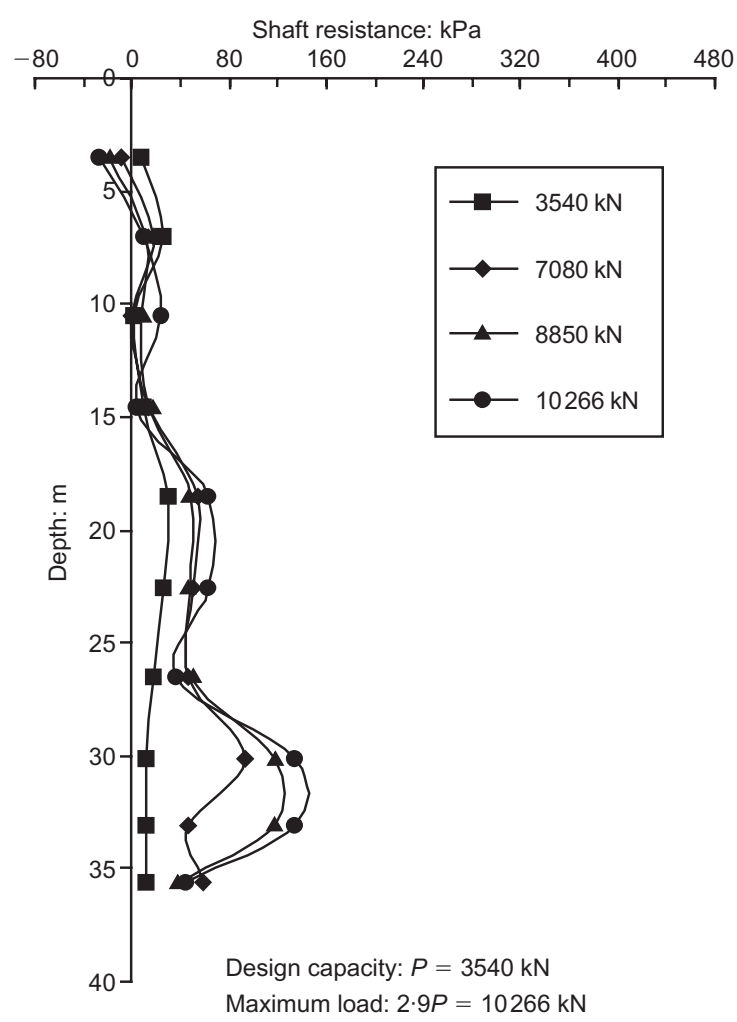

(a)

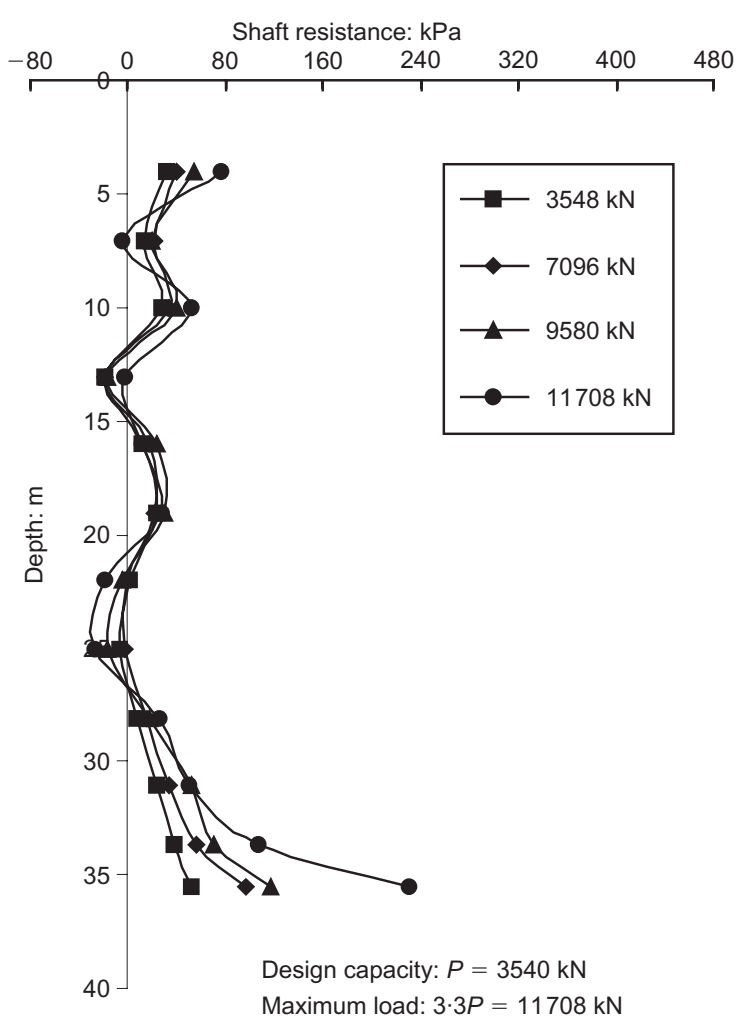

(b)

Fig. 11. Shaft resistance distribution for driven piles: (a) PD2; (b) PD8

in the second load cycle (before the creep stage), PJ1 settled by $\sim 43 \mathrm{~mm}$ and PJ8 settled by $\sim 36 \mathrm{~mm}$, implying that the stiffnesses of the two piles were comparable $(\sim 164 \mathrm{kN} / \mathrm{mm})$. However, it is noted that PJ1 suffered greater creep settle- ment than PJ8 under the maintained load condition. The termination criteria for pile jacking are considered to be responsible for this observation. Recall that PJ8 experienced three cycles of preloading at a level of 2.5 times the design 


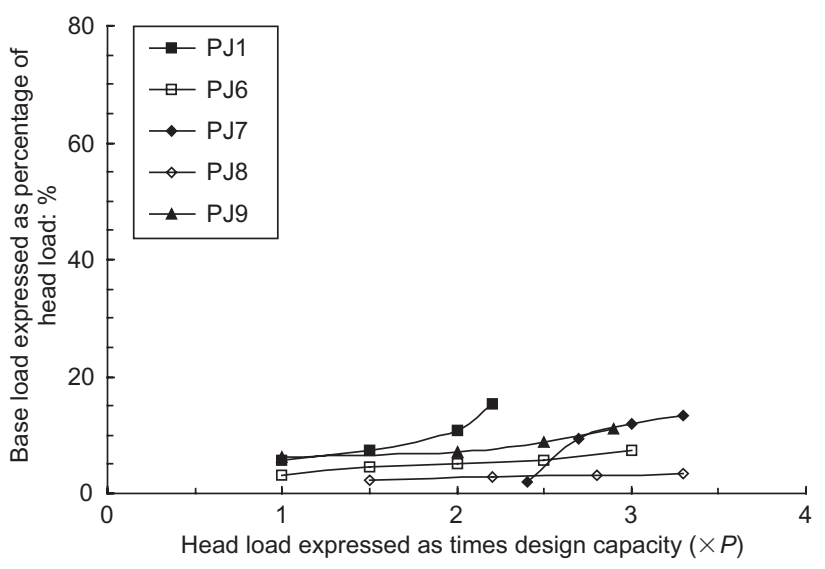

(a)

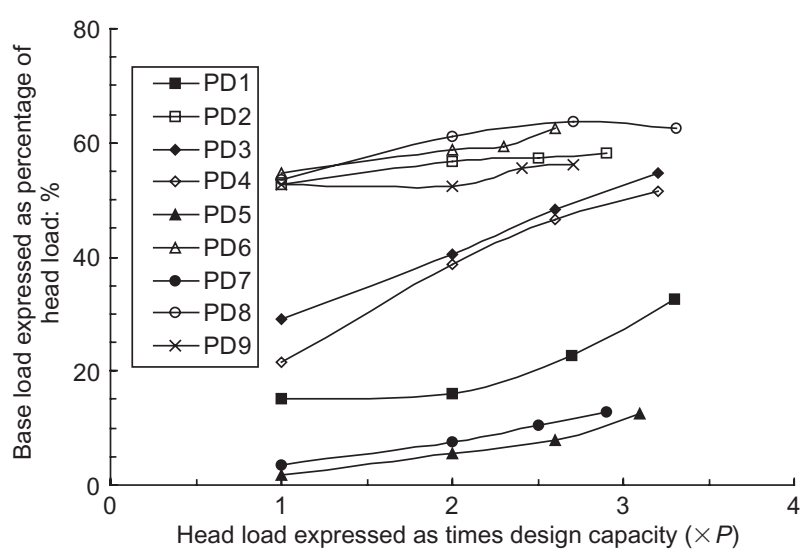

(b)

Fig. 12. Variation of percentages of pile head load carried by base: (a) jacked piles; (b) driven piles

capacity whereas PJ1 was subjected to only one preloading cycle at a lower level (twice the design capacity). As is widely known for soft soil treatment, the preloading effect is significant for reducing creep settlement.

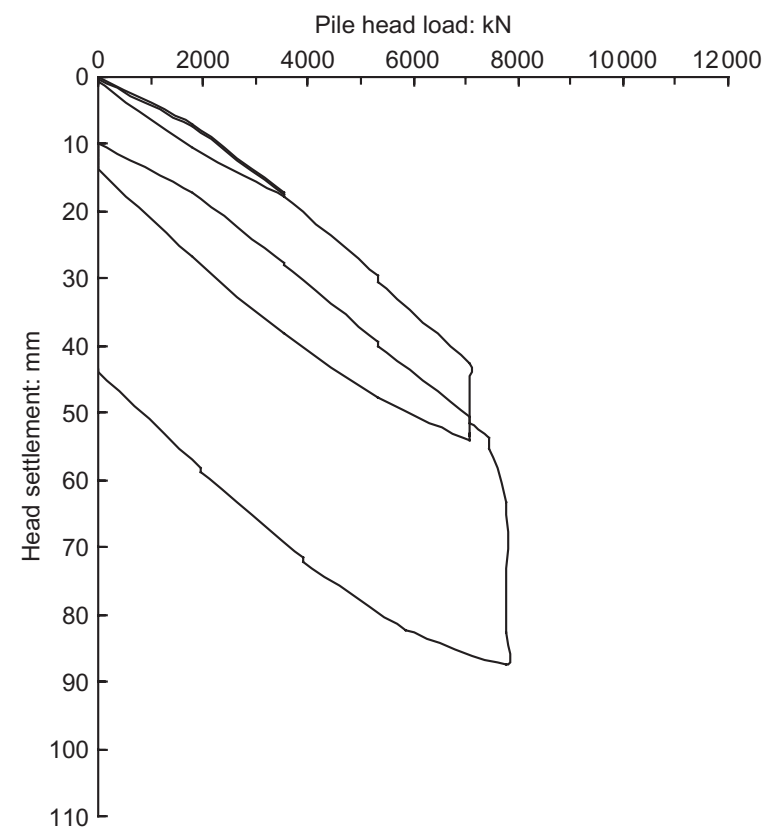

(a)
To better assess the preloading effect, the maximum jacking loads and the maximum loads attained in the load tests for all five jacked piles are compared with their design capacity in Fig. 15(a), and the creep and residual settlements measured for the five piles are compared in Fig. 15(b). Note that the creep settlement is defined as the settlement cumulated during the maintaining period, whereas the residual settlement is the head settlement measured after the maintained load is released (Fig. 7). Clearly, there is a striking difference between PJ1 and the other jacked piles. The average creep settlement for all five jacked piles was about $3 \mathrm{~mm}$; however, if PJ1 is excluded, the mean value becomes $1.37 \mathrm{~mm}$. It is interesting to note that this value is comparable to the average creep settlement measured for all driven piles $(\sim 1.29 \mathrm{~mm})$.

Comparison of the load-deflection diagrams in Fig. 14 for two driven piles indicates that the stiffnesses of the two piles are similar in magnitude. In the second load cycle, PD2 settled by $\sim 42 \mathrm{~mm}$ while PD8 settled by $\sim 41 \mathrm{~mm}$ at a load level of twice the design capacity (before the creep stage). While somewhat unusual heave was measured for PD2 after the second load cycle, the test showed that it had no detrimental effect on pile load capacity or load-deflection characteristics. In the final loading cycle, the pile settled by $\sim 40 \mathrm{~mm}$ under twice the design capacity, and the maximum load attained was up to 2.9 times the design capacity.

It is possible to derive the load-deformation characteristics in a more meaningful manner, as shown in Figs 16 and 17, where the relationship between local shaft resistance and local displacement (the so-called $t-z$ response) is established at various depths for the jacked and driven piles. The local displacement is simply defined herein as the difference between pile head settlement and the elastic shortening of the pile shaft above the depth under consideration.

Figures 16 and 17 indicate that, although the curves share similar shapes for the jacked and driven piles, the shaft resistance of the jacked piles is generally stiffer and stronger than that of the driven piles. At a given depth, jacked piles tend to show a higher local shaft resistance. A better comparison can be made using data for PJ1 and PD2, as both piles had close embedment lengths $(\sim 40 \mathrm{~m})$, were installed at the same site, and were loaded close to plunging failure.

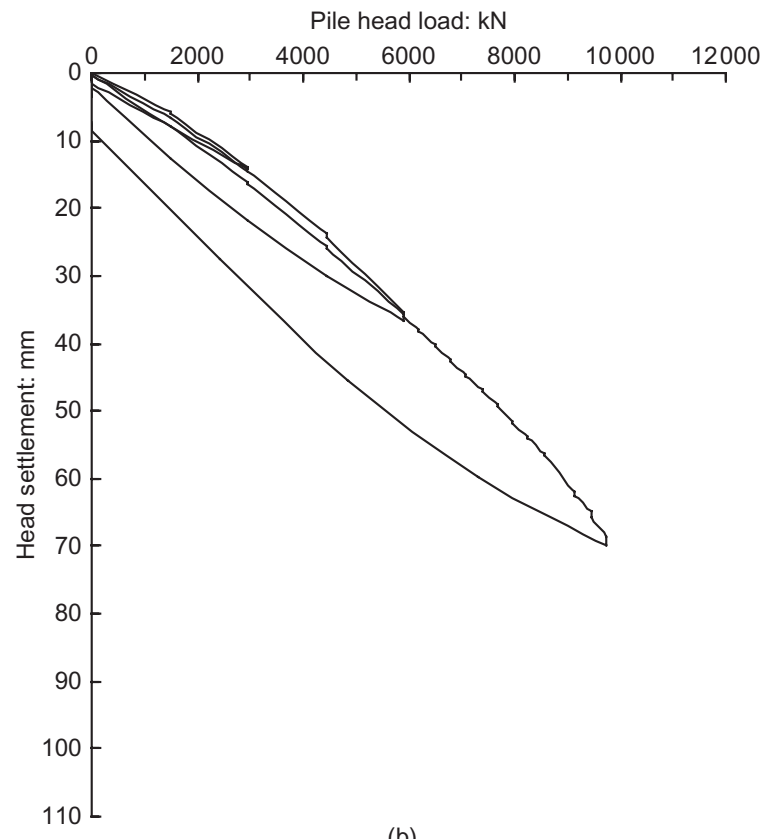

(b)

Fig. 13. Load-settlement curves of jacked piles: (a) PJ1; (b) PJ8 


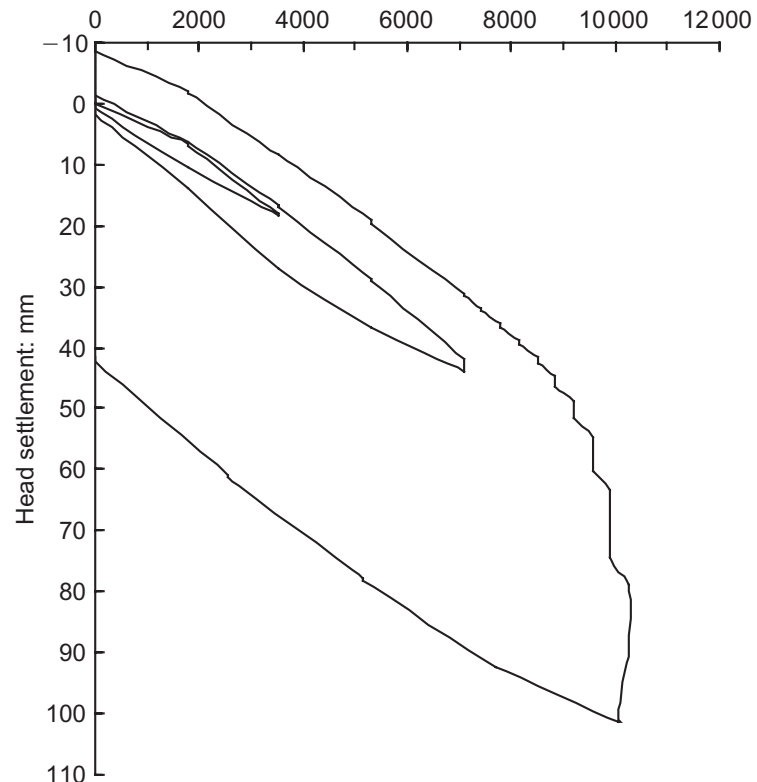

(a)

Fig. 14. Load-settlement curves of driven piles: (a) PD2; (b) PD8

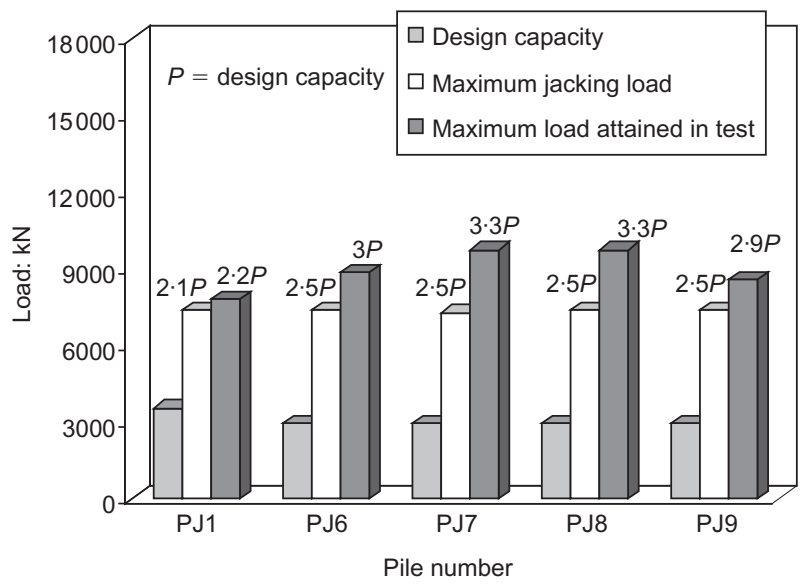

(a)

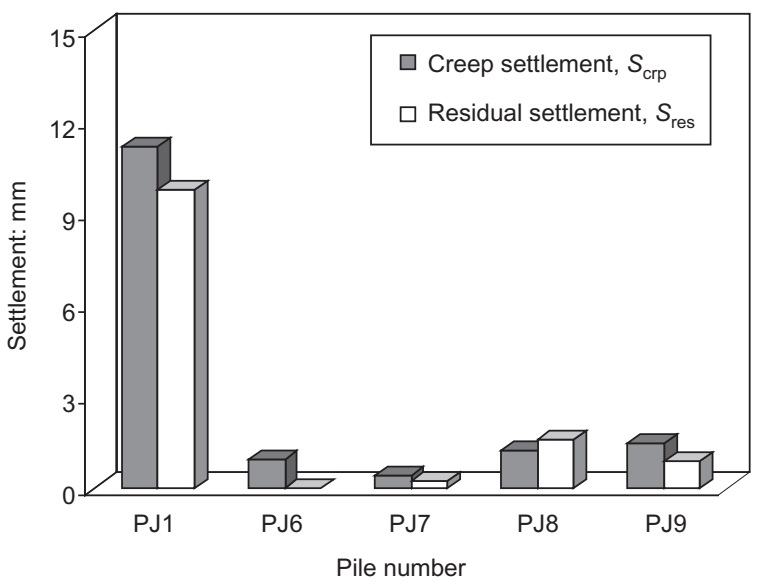

(a)

Fig. 15. Effect of precreeping on behaviour of jacked piles: (a) load capacity; (b) settlement

This comparison is shown in Fig. 18, where the shaft resistance-displacement responses of the two piles at a similar depth are put together. The fatigue mechanism that has been well described by White \& Lehane (2004) using

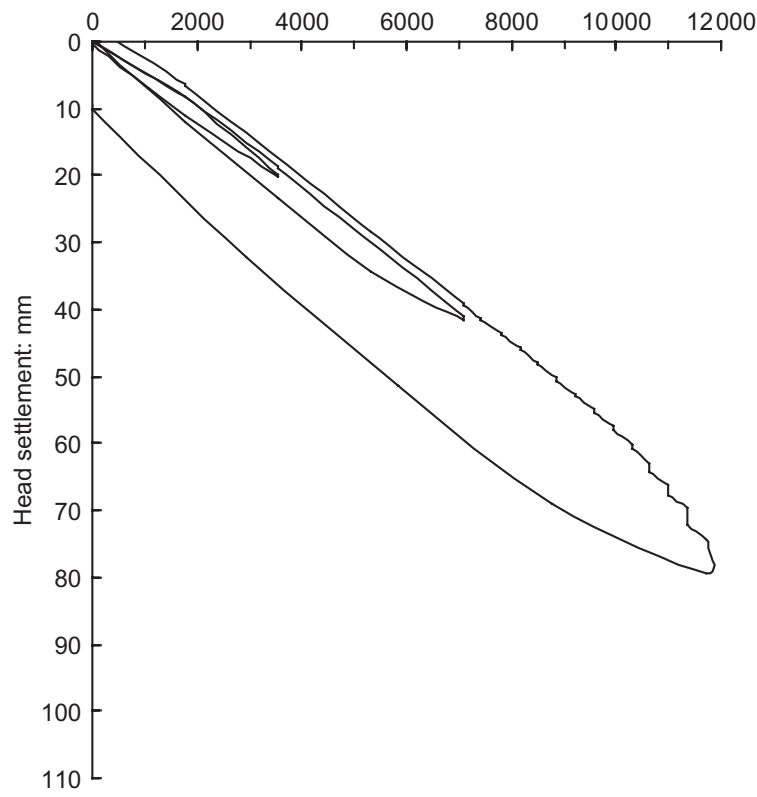

(b)

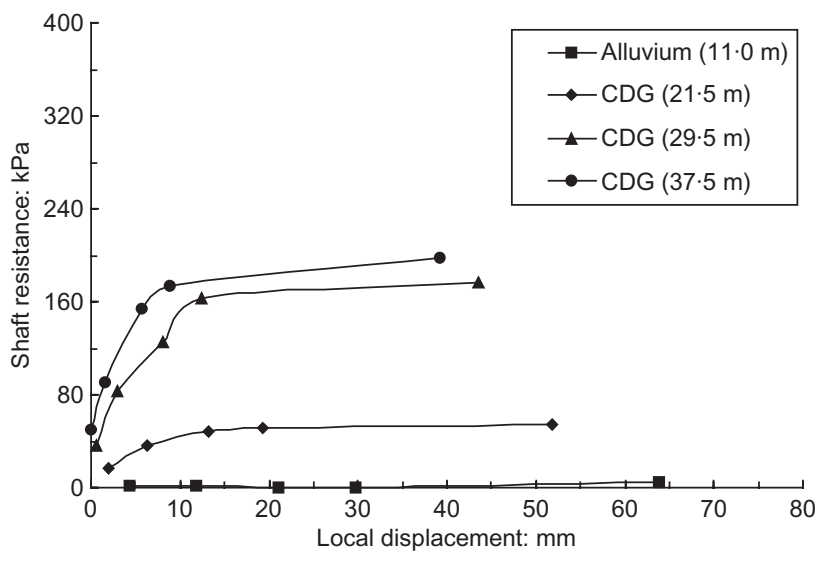

(a)

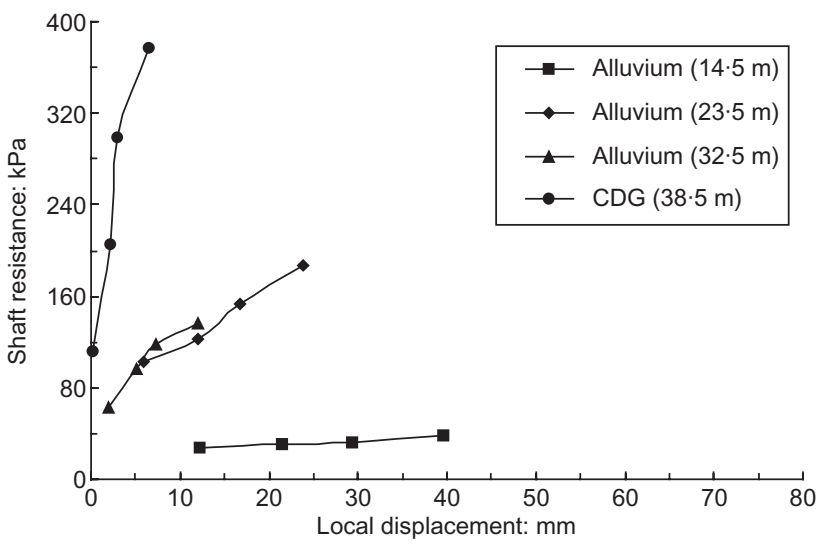

(b)

Fig. 16. Shaft resistance against displacement: (a) PJ1; (b) PJ8

centrifuge model tests could explain the observed difference in Fig. 18. Compared with a jacked pile, a driven pile normally experiences a significantly larger number of loading/unloading cycles during installation, and consequently 


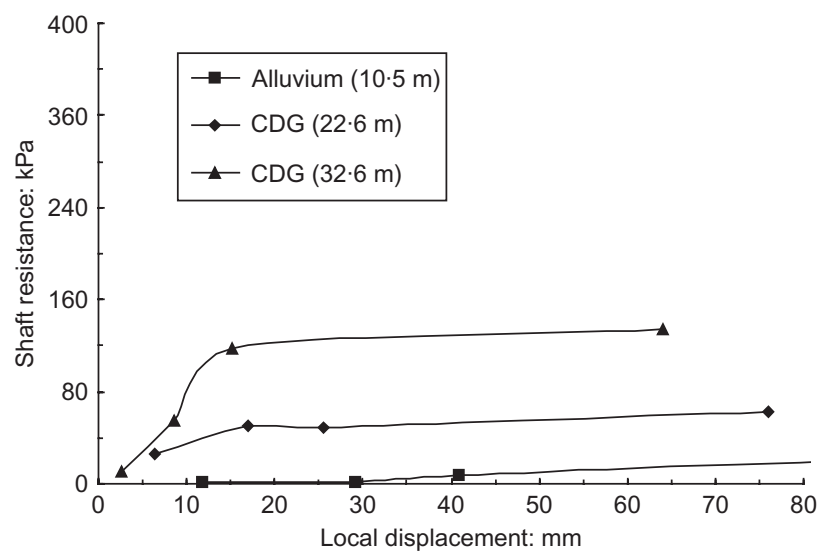

(a)

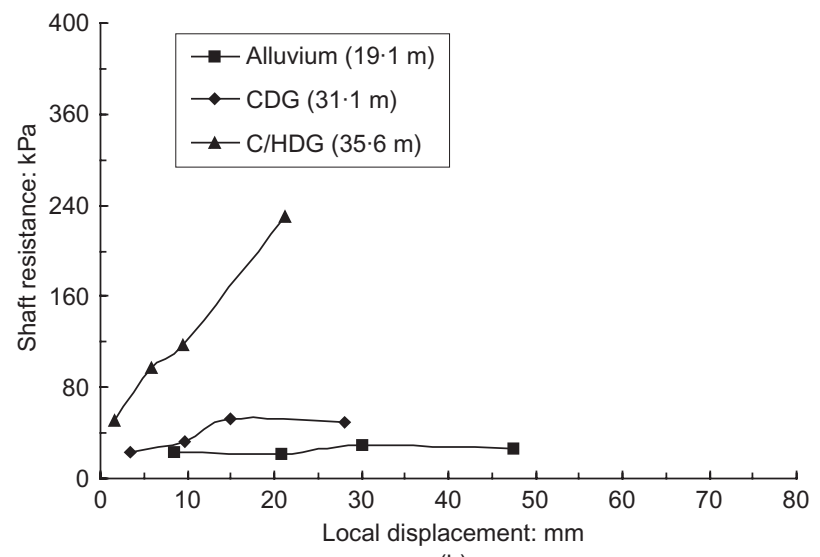

(b)

Fig. 17. Shaft resistance against displacement: (a) PD2; (b) PD8

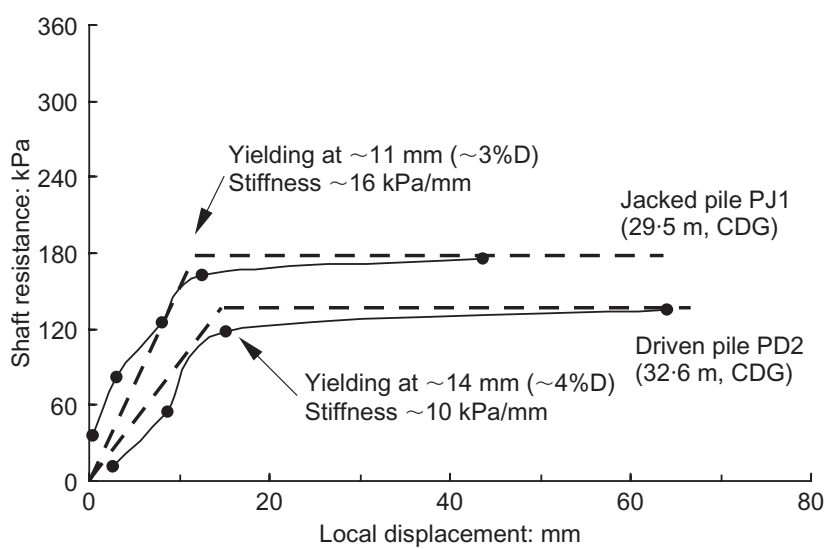

Fig. 18. A close comparison of shaft resistance-displacement responses of jacked and driven piles

will show degraded stiffness and shaft resistance in the $t-z$ response.

Similarly, the relationship between base resistance and tip settlement can be established, as shown in Fig. 19. The base settlement is determined by subtracting the elastic shortening of the pile shaft from the head settlement. Generally, the relationship can be reasonably described using a hyperbolic curve. At a settlement of $\sim 5 \mathrm{~mm}$, the jacked piles mobilised a base resistance of between 10 and $20 \mathrm{MPa}$, whereas the majority of driven piles showed a higher base resistance varying from 100 to $180 \mathrm{MPa}$. It is noted again that the three piles PD1, PD5 and PD7 fall far below the majority,

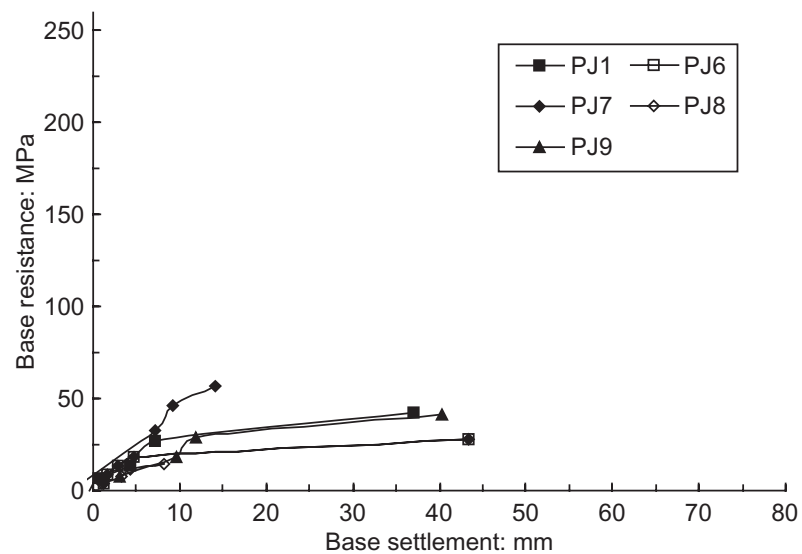

(a)

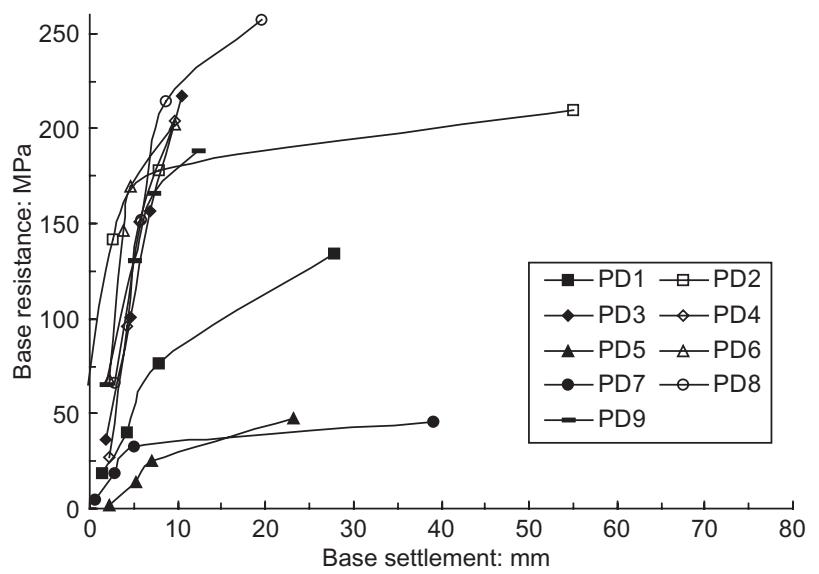

(b)

Fig. 19. Base resistance against displacement: (a) jacked piles; (b) driven piles

mobilising a base stress of about $30 \mathrm{MPa}$ at a settlement of $\sim 5 \mathrm{~mm}$.

\section{PRACTICAL IMPLICATIONS AND DISCUSSION}

In the practical design of piles in sandy soil, an effective stress analysis is considered to be appropriate, as the soil is highly permeable. Based on Coulomb's friction law, the ultimate shaft resistance at a depth $f_{\max }$ can be calculated as

$$
f_{\max }=K \sigma_{\mathrm{v}}^{\prime} \tan \delta
$$

where $\sigma_{\mathrm{v}}^{\prime}$ is the effective overburden pressure at the depth under consideration, $K$ is the lateral earth pressure coefficient, and $\delta$ is the friction angle of the pile-soil interface.

The angle $\delta$ depends on the nature of the pile shaft and the surrounding soil, and can be reasonably determined using shear box tests. For practical purposes, it is often assumed to be equal to a fraction of the angle of the shearing resistance of the surrounding soil, $\phi^{\prime}$. The coefficient $K$ depends on various factors including the state of the soil, the method of pile installation, and the geometry of the pile, and can be related to the in situ earth pressure coefficient $K_{0}$. Therefore equation (4) can be rewritten as

$$
f_{\max }=K_{0}\left(\frac{K}{K_{0}}\right) \tan \left[\phi^{\prime}\left(\frac{\delta}{\phi^{\prime}}\right)\right] \sigma_{\mathrm{v}}^{\prime}
$$

Some proposals have been made for the ratios $K / K_{0}$ and $\delta / \phi^{\prime}$. For example, it has been suggested that $\delta / \phi^{\prime}$ is in the range $0.5-0.7$ for smooth steel pipe piles or H-piles and 
$0 \cdot 8-1.0$ for smooth concrete piles, and that $K / K_{0}$ is in the range $0 \cdot 7-1 \cdot 2$ for small-displacement piles and $1 \cdot 0-2 \cdot 0$ for large-displacement piles (Kulhawy, 1984). In practice, the effects of $K$ and $\delta$ are usually combined into a single shaft friction coefficient $\beta$, such that (Burland, 1973)

$$
f_{\max }=\beta \sigma_{\mathrm{v}}^{\prime}
$$

Many proposals have been put forward for the selection of appropriate values for $\beta$. In Hong Kong, typical values of $\beta$, given by Davies and Chan (1981), have been commonly used (GEO, 1996). According to Davies and Chan (1981), the range of $\beta$ is $0.4-1.0$ for driven piles in loose sand, and $1 \cdot 0-2 \cdot 0$ for driven piles in dense sand (Table 5). This implies that there may be a fairly large variation in shaft resistance.

Based on the data from the load tests, an attempt is made herein to establish the relationship between the ultimate shaft resistance and the effective vertical stress for both jacked and driven piles. Before doing that, the point should be emphasised that in most pile load tests the piles may not achieve the ideal plunging failure, although they may be determined to 'fail' according to some settlement-related criterion; rather, the pile usually exhibits a progress failure mechanism, as shown schematically in Fig. 20. The load tests of this study lend good support to this notion. Therefore only the data points that show a limiting value of the shaft resistance being reached are used in establishing the relationship for $\beta$ (Fig. 21). This figure indicates that values of $\beta$ can be assumed to be in the range $0 \cdot 25-0 \cdot 6$ for all test piles. Note that the values are significantly lower than the lower bound suggested by Davies and Chan (1981) for driven piles in dense sand.

Various factors may contribute to this discrepancy, including soil property and pile type. Note that Davies and Chan (1981) did not differentiate between the types of driven pile or the types of sand. As all of the test piles in this study were small-displacement H-piles, which do not cause as much disturbance to the surrounding soil as do large-displacement driven piles (e.g. close-ended concrete or closeended steel pipe piles), and the soils involved in the field tests were not clean silica sand but a type of silty sand, the range of values for $\beta$ is considered to be reasonable.

An alternative estimate of $\beta$ has also been attempted using equation (5). In the first instance, the soils are presumably considered to be normally consolidated, and the earth pressure coefficient $K_{0}$ is approximately estimated by $K_{0}=$ $1-\sin \phi^{\prime}$. For a set of possible values of the friction angle of the soil and the $\delta / \phi^{\prime}$ and $K / K_{0}$ ratios, values of $\beta$ are calculated and tabulated in Table 6 . It is noted that selection of $\delta / \phi^{\prime}=0.7-0.9$ and $K / K_{0}=1.2-1.5$ tends to give estimates of $\beta$ that are close to the back-calculated values.

The above discussion highlights that there are many uncertainties involved in the practical performance of displacement piles in sandy soil. It is for this reason that empirical methods have been widely used in the design (Randolph, 2003). These methods are based primarily on

Table 5. Typical values of shaft friction coefficient in sand (after Davies \& Chan, 1981; GEO, 1996)

\begin{tabular}{l|c|c}
\hline Type of pile & Type of soil & $\begin{array}{c}\text { Shaft friction } \\
\text { coefficient, } \beta\end{array}$ \\
\hline Driven piles & Loose sand & $0 \cdot 4-1 \cdot 0$ \\
Driven piles & Dense sand & $1 \cdot 0-2 \cdot 0$ \\
Bored piles & Loose sand & $0 \cdot 15-0 \cdot 3$ \\
Bored piles & Dense sand & $0 \cdot 25-0 \cdot 6$ \\
\hline
\end{tabular}

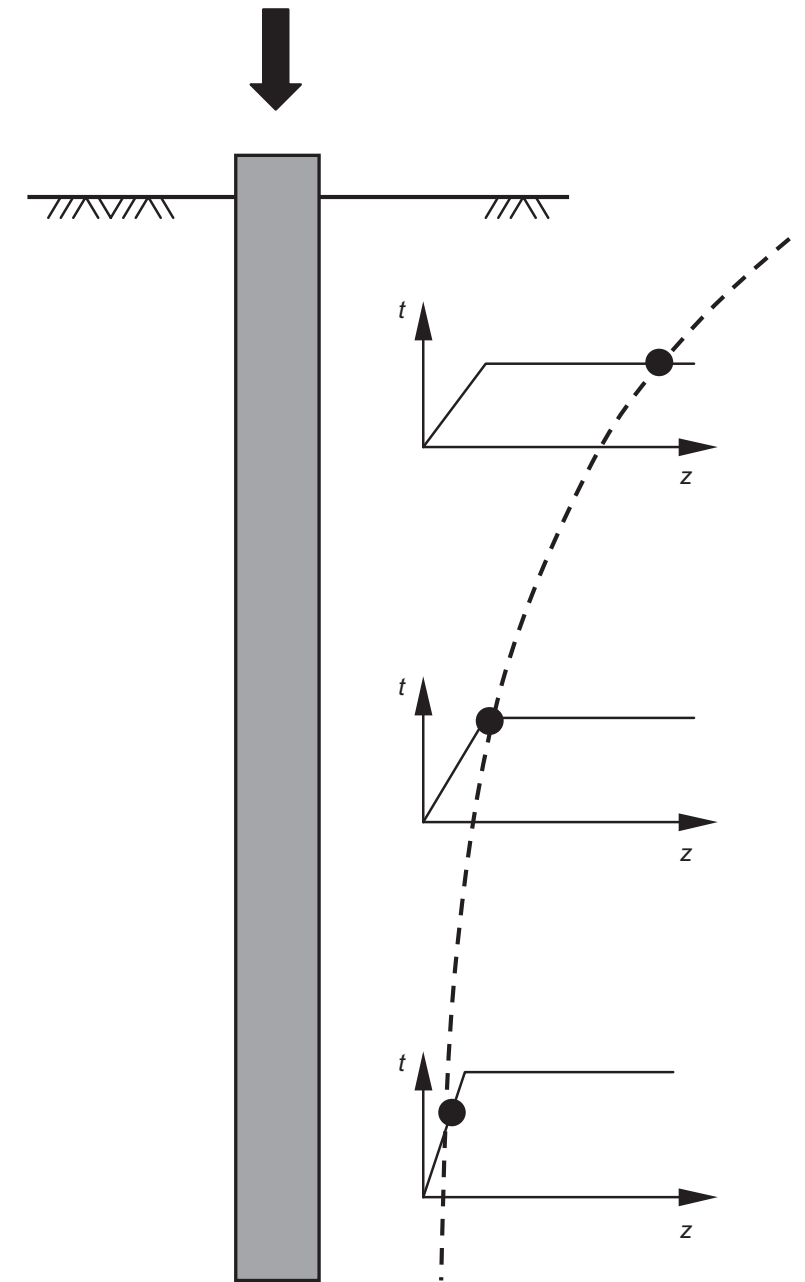

Fig. 20. Schematic of load transfer and progress failure mechanisms

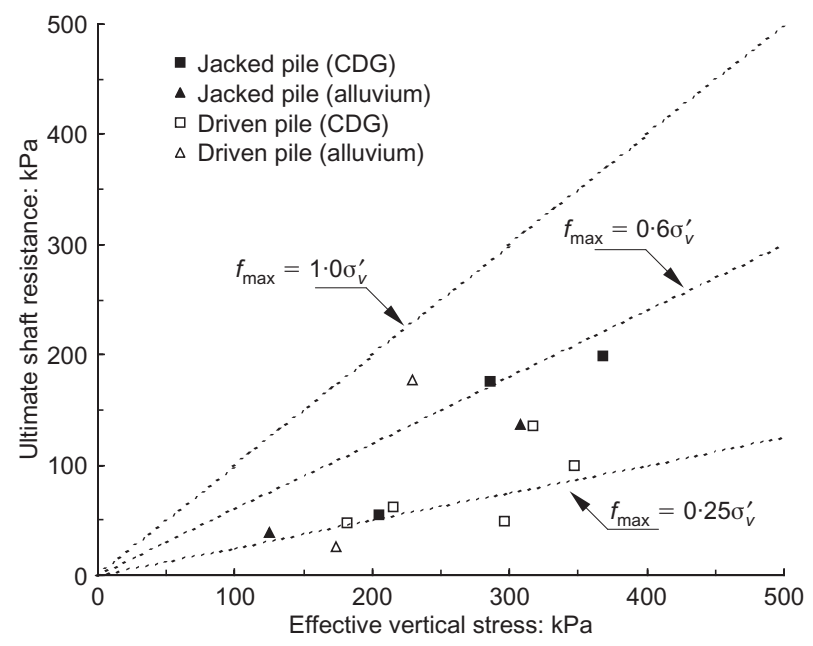

Fig. 21. Comparison between ultimate shaft resistance and effective overburden pressure

field tests such as CPT (cone penetration tests) and SPT. One of the common methods is that proposed by Meyerhof (1976), in which the pile shaft friction is estimated using SPT $N$ values. SPT tests, rather than the more advanced CPT tests, are commonly used for site investigation in local practice, because of the high resistance of residual soil. An attempt is hence made here to examine the correlation 
Table 6. Theoretical estimates of shaft friction coefficient

\begin{tabular}{|c|c|c|c|c|c|c|c|c|c|}
\hline \multirow{2}{*}{$\begin{array}{l}\text { Friction angle } \\
\text { of soil, } \phi^{\prime}: \text { deg }\end{array}$} & \multicolumn{9}{|c|}{ Shaft friction coefficient, $\beta$} \\
\hline & $\begin{array}{l}\text { Case 1-1 } \\
\delta=0 \cdot 5 \phi^{\prime} \\
K=1 \cdot 0 K_{0}\end{array}$ & $\begin{array}{l}\text { Case } 1-2 \\
\delta=0 \cdot 5 \phi^{\prime} \\
K=1 \cdot 2 K_{0}\end{array}$ & $\begin{array}{l}\text { Case } 1-3 \\
\delta=0 \cdot 5 \phi^{\prime} \\
K=1 \cdot 5 K_{0}\end{array}$ & $\begin{array}{l}\text { Case 2-1 } \\
\delta=0 \cdot 7 \phi^{\prime} \\
K=1 \cdot 0 K_{0}\end{array}$ & $\begin{array}{l}\text { Case 2-2 } \\
\delta=0 \cdot 7 \phi^{\prime} \\
K=1 \cdot 2 K_{0}\end{array}$ & $\begin{array}{l}\text { Case 2-3 } \\
\delta=0 \cdot 7 \phi^{\prime} \\
K=1 \cdot 5 K_{0}\end{array}$ & $\begin{array}{l}\text { Case } 3-1 \\
\delta=0 \cdot 9 \phi^{\prime} \\
K=1 \cdot 0 K_{0}\end{array}$ & $\begin{array}{l}\text { Case } 3-2 \\
\delta=0 \cdot 9 \phi^{\prime} \\
K=1 \cdot 2 K_{0}\end{array}$ & $\begin{array}{l}\text { Case } 3-3 \\
\delta=0 \cdot 9 \phi^{\prime} \\
K=1 \cdot 5 K_{0}\end{array}$ \\
\hline 30 & $0 \cdot 134$ & $0 \cdot 161$ & $0 \cdot 201$ & $0 \cdot 192$ & $0 \cdot 230$ & 0.288 & 0.255 & $0 \cdot 306$ & 0.382 \\
\hline 35 & $0 \cdot 134$ & $0 \cdot 161$ & $0 \cdot 202$ & $0 \cdot 194$ & 0.233 & $0 \cdot 291$ & 0.261 & $0 \cdot 314$ & 0.392 \\
\hline 40 & $0 \cdot 130$ & $0 \cdot 156$ & $0 \cdot 195$ & $0 \cdot 190$ & $0 \cdot 228$ & $0 \cdot 285$ & $0 \cdot 260$ & $0 \cdot 311$ & $0 \cdot 389$ \\
\hline 45 & $0 \cdot 121$ & $0 \cdot 146$ & $0 \cdot 182$ & $0 \cdot 179$ & $0 \cdot 215$ & $0 \cdot 269$ & $0 \cdot 250$ & $0 \cdot 300$ & $0 \cdot 375$ \\
\hline 50 & $0 \cdot 109$ & $0 \cdot 131$ & $0 \cdot 164$ & $0 \cdot 164$ & $0 \cdot 196$ & $0 \cdot 246$ & 0.234 & $0 \cdot 281$ & $0 \cdot 351$ \\
\hline
\end{tabular}

Note: $\delta=$ friction angle of soil-pile interface; $K_{0}=$ in situ earth pressure coefficient; $K=$ earth pressure coefficient defined in equation (4).

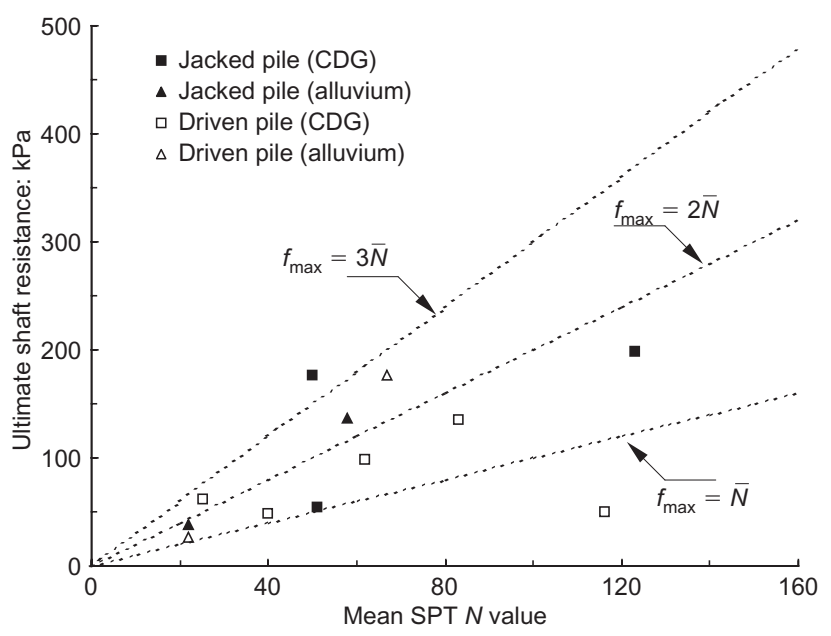

Fig. 22. Correlation between ultimate shaft resistance and mean SPT $N$ value

between the ultimate shaft resistance and SPT $N$ values, for both the jacked and the driven piles. The results of the analysis are shown in Fig. 22. As it is customary in local practice to use uncorrected SPT $N$ values, none of the $N$ values that are included in the graph is corrected for overburden pressure.

While unsatisfying scatter exists, there is a correlation between the ultimate shaft friction $f_{\max }$ and the average $N$ value, $\bar{N}$, for all the test piles. The correlation can be expressed as

$$
f_{\max }=1 \cdot 5 \bar{N} \text { to } 2 \bar{N}(\mathrm{kPa})
$$

It is interesting to note that the above correlation lends support to the local practice (GEO, 1996) in which the shaft friction for small-displacement driven H-piles is roughly estimated to be $1 \cdot 5 \bar{N}$ to $2 \bar{N}(\mathrm{kPa})$.

\section{CONCLUSIONS}

The similarities and differences between the behaviour of jacked piles and that of driven piles are of considerable interest, yet poorly understood owing to the lack of highquality field data. This paper describes a series of full-scale field tests on 14 instrumented H-piles in residual soils, of which five were installed by hydraulic jacking and nine were installed by dynamical driving. The test data allow the following major observations to be made.

(a) The shaft resistance of jacked piles is generally stiffer and stronger than that of driven piles, whereas the base resistance of jacked piles is weaker than that of driven piles. At a given depth, jacked piles tend to show a higher local shaft resistance. The fatigue mechanism is probably responsible for this observation.

(b) At a load level of twice the design capacity, the percentage of pile head load carried by base varies from $2 \%$ to $10 \%$ for jacked piles, with a mean value of $6 \%$, whereas for driven piles the percentage varies from $6 \%$ to $61 \%$, with a mean value of $38 \%$.

(c) The termination criterion can be critical to the performance of jacked piles. The residual settlement of a jacked pile can be very much reduced and the pile can achieve a high capacity when jacking is terminated using a precreeping or preloading procedure at a load level of 2.5 times the design capacity of the pile.

(d) The back-calculated values of the shaft friction coefficient $\beta$, defined as the ratio between the ultimate shaft resistance and the effective vertical stress, are in the range $0.25-0.6$ for both the jacked and driven piles.

(e) A correlation exists between the ultimate shaft resistance and the uncorrected SPT $N$ values for both the jacked and driven piles, which suggests that the ultimate shaft friction (in $\mathrm{kPa}$ ) can be taken as one and a half to two times the mean SPT $N$ value.

\section{ACKNOWLEDGEMENTS}

The authors would like to thank the Housing Authority of the Hong Kong Special Administrative Region Government for granting permission to publish the results of this study. The financial support provided by the Research Grants Council of Hong Kong (HKU7131/03E; G_HK032/04) and the University of Hong Kong (URC/11159066) is gratefully acknowledged. The contents of this paper do not necessarily reflect the views or policies of the Housing Authority, the Research Grants Council, or the University of Hong Kong.

\section{REFERENCES}

BD (Buildings Department) (2004). Code of Practice for Foundations. Buildings Department, The Government of the Hong Kong Special Administrative Region, Kowloon, Hong Kong.

Bolton, M. D. (1986). The strength and dilatancy of sands. Géotechnique 36, No. 1, 65-78.

Burland, J. B. (1973). Shaft friction of piles in clay: a simple fundamental approach. Ground Engng 6, No. 3, 30-42.

Chow, F. C. (1995). Field measurements of stress interactions between displacement piles in sand. Ground Engng 28, No. 6, $36-40$.

Craig, W. H. \& Sabagh, S. K. (1994). Stress-level effects in model tests on piles. Can. Geotech. J. 31, No. 1, 28-42.

Davies, R. V. \& Chan, A. K. C. (1981). Pile design in Hong Kong. Hong Kong Engineer 9, No. 3, 21-28.

Davisson, M. T. (1972). High capacity piles. Proceedings and Lecture Series in Innovations in Foundation Construction, ASCE, Illinois Section, 81-112. 
Fellenius, B. H. (2002). Discussion of 'Side resistance in piles and drilled shafts' by M. W. O’Neill. J. Geotech. Geoenviron. Engng, ASCE 128, No. 5, 446-448.

GEO (1996). Pile design and construction, GEO Publication No 1/96. Hong Kong: Geotechnical Engineering Office.

Hansen, B. J. (1970). A revised and extended formula for bearing capacity. Dan. Geotech. Inst. Bull. No. 28, 5-11.

Klotz, E. U. \& Coop, M. R. (2001). An investigation of the effect of soil state on the capacity of driven piles in sands. Géotechnique 51, No. 9, 733-751.

Kulhawy, F. H. (1984). Limiting tip and side resistance: fact or fallacy? Proc. Symp. Anal. Design of Pile Found, San Francisco, LA: American Society of Civil Engineers, pp. 80-98.

Lehane, B. M., Jardine, R. J., Bond, A. J. \& Frank, R. (1993). Mechanisms of shaft friction in sand from instrumented pile tests. J. Geotech. Engng, ASCE 119, No. 1, 19-35.

Li, K. S., Ho, N. C. L., Tham, L. G. \& Lee, P. K. K. (2003). Case studies of jacked piling in Hong Kong. Hong Kong: Centre for Research and Professional Development and The University of Hong Kong.

Lumb, P. (1962). The properties of decomposed granite. Géotechnique 12, No. 3, 226-243.

Lumb, P. (1965). The residual soils of Hong Kong. Géotechnique 15, No. 2, 180-194

Mesri, G., Ajlouni, M. A., Feng, T. W. \& Lo, D. O. K. (2001).
Surcharging of soft ground to reduce secondary settlement. Proc. 3rd Int. Conf. Soft Soil Engng, Hong Kong, 55-65.

Meyerhof, G. G. (1976). Bearing capacity and settlements of pile foundations. J. Geotech. Engng Div., ASCE 102, No. GT3, $197-228$

Randolph, M. F. (2003). Science and empiricism in pile foundation design. Géotechnique 53, No. 10, 847-875.

Randolph, M. F., Dolwin, J. \& Beck, R. (1994). Design of driven piles in sand. Géotechnique 44, No. 3, 427-448.

Tomlinson, M. J. (1994). Pile design and construction practice, 4th edn. London: E \& FN Spon.

Vesic, A. S. (1970). Tests on instrumented piles, Ogeechee River site. J. Soil Mech. Found. Div., ASCE 96, No. SM2, 561-584.

White, D. J. \& Lehane, B. M. (2004) Friction fatigue on displacement piles in sand. Géotechnique 54, No. 10, 645-658.

Yang, J. (2005). Discussion of 'Shaft resistance of single vertical and batter piles driven in sand' by A. Hanna and T. Nguyen.

J. Geotech. Geoenviron. Engng, ASCE 131, No. 1, 137-138.

Yang, J. \& Li, X. S. (2004). State-dependent strength of sands from the perspective of unified modeling. J. Geotech. Geoenviron. Engng, ASCE 130, No. 2, 186-198.

Yang, J., Tham, L. G., Lee, P. K. K. \& Yu, F. (2006). Observed performance of long steel H-piles jacked into sandy soil. J. Geotech. Geoenviron. Engng, ASCE 132, No. 1, 24-35. 